Pamiętnik Literacki 2020, 1, s. 137-170

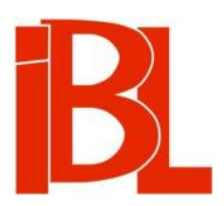

\title{
Tak zwana "Wenecjanka". Hipotezy dotyczące atrybucji i kulturowego obiegu włoskiej melodii popularnej w dobie oświecenia
}

Lidia Ignaczak 


\title{
TAK ZWANA „WENECJANKA” HIPOTEZY DOTYCZACEE ATRYBUCJI I KULTUROWEGO OBIEGU WŁOSKIEJ MELODII POPULARNEJ W DOBIE OŚWIECENIA
}

\begin{abstract}
À part
Sa przypadki zgryzot naukowych, które, choć - wydawałoby się - niewielkie, odbierają badaczowi wewnętrzny spokój. Przypomnę intymny wpis z Raptularza Zbigniewa Raszewskiego, dotyczący prób ustalenia, czy Wojciech Bogusławski był żonaty tylko raz, czy może dwukrotnie: „Skąd, do jasnej cholery, Bogusławski wy-

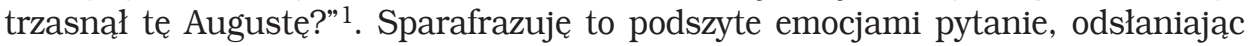
własną małą zgryzotę muzykologiczno-teatrologiczną: skąd Bogusławski wytrzasnął melodię arii Starego Dominika? Mam tu na myśli popularną w latach dziewięćdziesiątych XVIII wieku solową partię o inc. „Patrzcie, bogacze świata” z aktu III Taczki occiarza $a^{2}$.
\end{abstract}

\section{„Wenecjanka" w teatrze}

Sztukę Louisa-Sébastiena Merciera w polskim przekładzie Bogusławskiego wystawiono w Teatrze Narodowym w latach 1790-1793 - jak podaje Ludwik Bernacki aż 23 razy $^{3}$, a tekst piosnki Starego Dominika, winkrustowanej weń przez tłumacza, upowszechniany był w formie druku ulotnego wydanego „na żądanie publiczności” która ochoczo śpiewała podchwycony motyw melodyczny.

Czy istotnie Bogusławski dodał piosenkę Starego Dominika do sztuki Merciera przede wszystkim po to, by - jak sugeruje Raszewski, a za nim Marek Dębowski, badający językowy kształt przekładu dramy Merciera, i Agnieszka Kozyra, opracowująca współczesną edycję Taczki occiarza - popisać się swym pięknym basso

1 Z. Ras zew ski, Raptularz. T. 1. Londyn 2004, s. 187 (słowa pisane w r. 1966).

2 Na afiszu zapowiadającym warszawska premierę widniał nadany przez W. B o gus a aw ski e go tytuł Taczka przedajacego ocet $i$ musztardę, czyli Cnota $w$ grubej łachmanie (premiera: Teatr Narodowy w Warszawie, 23 X 1790). Taczka occiarza była polską adaptacją sztuki L.-S. M e r c i e r a La Brouette du vinaigrier. Drame en trois actes (premiera: Théâtre de Maestricht, 1774; wyd. London-Paris 1775).

3 L. Berna cki: Teatr, dramat i muzyka za Stanisława Augusta. T. 1: Źródta i materiały. Lwów 1925, s. 342, 395; jw., t. 2: Notatki i studia, s. 211. Zob. też J. Pro k o p, „Taczka occiarza” Merciera i jej recepcja $w$ teatrze Bogusławskiego. „Pamiętnik Teatralny” 1954, z. 3/4.

4 Cyt. za: Z. Ras zew ski, Bogusławski. T. 1. Warszawa 2015, s. 213. 
caricato $?^{5} \mathrm{O}$ tym trudno wyrokować, na pewno jednak istniały dwie inne ważne przesłanki - pośrednio wspomniał o nich zresztą sam autor Dziejów Teatru Narodowego: chęć poprawy gustu polskiej publiczności oraz pragnienie zwiększenia dochodów $z$ wystawień sztuki, która już w wersji oryginalnej cieszyła się powodzeniem $^{6}$. Amplifikowanie utworów teatralnych, zwłaszcza komediowych, wstawkami muzycznymi stanowiło sprawdzony sposób na emocjonalne ożywianie publiczności, podtrzymywanie jej zaciekawienia daną sztuka; wykorzystywano do tego celu dobrze znane tematy muzyczne, z którymi widzowie byli osłuchani i które lubili ${ }^{7}$. Piosenka Starego Dominika okazała się rozwiązaniem uatrakcyjniającym Taczkę occiarza tak skutecznie, że sztukę powtarzano ku uciesze widzów wielokrotnie, dzięki czemu „nieledwie połowę całorocznych stanowiła przychodów”. Potwierdzenie finansowego osiagnięcia odnajdziemy w niepozbawionym kąśliwości powiedzeniu:

Gdy antrepryzie braknie grosza w kasie,

Zaraz na scenę $z$ swoją Taczka pcha się 8 .

Podchwycona przez Bogusławskiego melodia była do tego stopnia popularna, że jej swobodne krążenie w obiegu ustnym zatarło ścieżkę prowadzącą do jej włoskiego autora ${ }^{9}$. Charakteryzując tę śpiewkę $z$ perspektywy lat pięćdziesiatych wieku XX, Jan Prosnak przyporządkował tekst Bogusławskiego do linii melodycznej odnotowanej w wieku XIX przez Oskara Kolberga (który przywiazywał dużą wagę do procesu przejmowania pieśni o proweniencji teatralnej przez regionalny folklor ${ }^{10}$.

W roku 1986 Raszewski uzupełnił wiedzę o tajemniczej „Wenecjance”, wska-

5 Ibidem, s. 210. - M. D ę bow ski, Francuskie konteksty teatru polskiego $w$ dobie oświecenia. Kraków 2001, s. 74. - A. Ko zy r a, „Taczka occiarza” Wojciecha Bogusławskiego. Edycja krytyczna ze wstepem. Praca magisterska. Uniwersytet Łódzki, 2018, s. 31 (dysertacja ta jest podstawa publikacji, która ukaże się nakładem Wydawnictwa Uniwersytetu Łódzkiego w r. 2020: „Taczka occiarza" Wojciecha Bogusławskiego. Oprac., wstęp A. Ko zy ra. Red. nauk. B. Wolska).

6 W. B o g u sła w s ki, Dzieje Teatru Narodowego, na trzy części podzielone, oraz Wiadomość o życiu sławnych artystów. Warszawa 1965 (reprint wyd. z r. 1820), s. 68-69: „Piosneczka na notę upodobanej naówczas arii włoskiej, Veneciana zwanej, dla braku zapewne polskich oper, tak przyjemne publiczności sprawiła wrażenie, że przez resztę zimy wielokrotnie i bez uprzykrzenia powtarzana, nieledwie połowę całorocznych stanowiła przychodów. Była to pierwsza iskra obudzającego się dobrego smaku, te bowiem lat trzy następnych, coraz lepszymi dziełami i coraz bardziej wzrastającym w nich upodobaniem widzów, mocno zbliżyły ojczystą scenę do wyższej doskonałości”.

7 Ra s ze w s ki (Bogusławski, t. 1, s. 210) zwraca uwagę na mnemotechniczną rolę kupletów w XVIII-wiecznych teatrach jarmarcznych; z tradycji tej korzystał później teatr oświeceniowy. Zob też B. Gru n, Dzieje operetki. Przeł. M. Ku r e cka. Kraków 1974, s. 33-34. - Ra s ze w s ki, Bogusławski, t. 1, s. 213.

8 Cyt. za: A. Zalewski, Krótka kronika teatru polskiego. Źródła i materiały. (1814). W: Bern a cki, op. cit., t. 1, s. 395. Zob. też M. Ka ra s ow s ki, Rys historyczny opery polskiej poprzedzony szczegótowym pogladem na dzieje muzyki dramatycznej powszechnej. Warszawa 1859, s. 243.

9 Z. Ra szew s ki (Na nutę, Wenecjanki”. 〈1986〉. W: Trudny rebus. Studia i szkice z historii teatru. Wrocław 1990, s. 150) przekonywał, że trzeba uznać tę melodię za niezidentyfikowaną, póki nie znajdą się dokumenty pozwalające ustalić jej pochodzenie.

10 J. Prosnak, Kultura muzyczna Warszawy XVIII wieku. Kraków 1955, s. 257 (zapis nutowy i tekst). - O. Kolb e r g, Lud, jego zwyczaje, sposób życia, mowa, podania, przysłowia, obrzędy, gusła, zabawy, pieśni, muzyka i tańce. Seria 6: Krakowskie, cz. 2. Kraków 1873, s. 271-272 (piosenka zanotowana jako „spiew ogrodnika z komedii Taczka”, umieszczona tematycznie w podzbio- 
zując jako źródło kolejnej notacji muzycznej tego szlagieru spisany przez Gustawa, syna księcia kurlandzkiego Karola Ernesta Birona, dziennik, w którym zarejestrowana została wersja owej piosnki w opracowaniu na klawesyn ${ }^{11}$. Przytoczmy słowa badacza:

Dotychczas znaliśmy ją [tj. melodię piosenki] wyłącznie z Kolberga, który ją zapisał późno i - jak dziś można stwierdzić - w postaci dość zniekształconej. W dzienniczku Gustawa Birona mamy zapis z epoki, sporządzony tuż po premierze, a więc bez wątpienia poprawniejszy. Chłopiec nie notował sam tych nut, można to stwierdzić przyglądając się słowom „dal segno” nad ostatnim taktem. Nie są one napisane ręką Gustawa. Najprawdopodobniej ktoś z orkiestry wpisał te nuty do dzienniczka, na prośbę chłopca (czy raczej jego guwernera) ${ }^{12}$.

Zasugerowane przez Raszewskiego pokrewieństwo nazwy piosnki Starego Dominika $z$ tytułami takich pieśni, jak Marsylianka czy Warszawianka, pozwala nam wnioskować, że melodia arii z Taczki occiarza powstała w Wenecji i osiagnęła popularność, która umożliwiła jej wykroczenie poza obieg regionalny. Spolszczona nazwa „Wenecjanka” 13 świadczy o tym, że dla warszawskiej publiczności utwór był tak ważny, iż spośród innych piosenek teatralnych o włoskiej proweniencji wyodrębniono go za pomocą charakterystycznej nazwy własnej. Wydaje się jednak, że użyteczniejszy w ustaleniu pochodzenia melodii z Taczki occiarza jest fragment Dziejów Teatru Narodowego, gdzie Bogusławski określił piosenkę Starego Dominika mianem „arii włoskiej, Veneciana zwanej” ${ }^{14}$. Prawdopodobnie polski tytuł powstał jako przetworzenie wyrażenia „aria veneziana [lub: venetiana]”, który nie tylko odsyłał do miejsca jej powstania, ale również określał specyfikę języka pieśni (dialekt wenecki), repetycyjność melodii i swoistość wykonania, co pozwalało odróżnić ów model śpiewu od arii napoletana ${ }^{15}$. Trudno więc uznać termin „aria veneziana”

rze Dom, Gośc). Zob. też zapis nutowy znajdujący się w artykule Ras zewskiego (Na nutę „Wenecjanki”, s. 148) - aneks I 1.

11 Raszews ki, Na nutę „Wenecjanki”, s. 149 - zob. aneks I 2.

12 Ibidem, s. 150.

13 Taka nazwę znajdziemy na zachowanych drukach ulotnych upowszechniających słowa piosnki Starego Dominika, które to druki rozrzucono na widowni 24 X 1790, w czasie drugiego wystawienia Taczki occiarza - pisze o tym Z. Raszewski w Krótkiej historii teatru polskiego (Wyd. 3, przejrz. Warszawa 1990, s. 75). Tradycja popularyzowania numerów słowno-muzycznych na drukach ulotnych utrzyma się dłużej, podobnie zresztą jak upowszechnianie piosenek w odpisach, o którym to zwyczaju wspomina F. Karpiński, obdarowany takim zapisem piosenki Bardosa z Cudu mniemanego. Zob. T. Mi k u ls k i, Piosenka z „Krakowiaków i górali” w papierach Karpińskiego. „Pamiętnik Teatralny” 1954, z. 3/4. - Ras zews ki, Bogusławski, t. 1, s. 311.

Słynne arie operowe gromadzono w śpiewnikach. Znamienne, że w tych z przełomu XVIII i XIX w. (np. Rozrywka w smutku, czyli Piosnki i arie zebrane roku 1796. Warszawa [po 1796], s. 3-4. Bibl. Jagiellońska, sygn. 5136 I. - Piosnki i arie z różnych operów i komedii zebrane, wiela nowymi tekstami pomnożone. B. m., 1806, s. 2-3. Jw., sygn. 5222 I) śpiewka Starego Dominika zwykle otwiera zbiór - świadczy to o kulturowej randze owego numeru.

14 Bogusław s ki, Dzieje Teatru Narodowego [...], s. 68.

15 Zob. hasło „aria” (,aria veneziana”, „aria napoletana”) w: J. Habela, Słowniczek muzyczny. Wyd. 9. Kraków 1977, s. 17-18. - A. J a c o b s, Słownik muzyczny. Przeł. H. Mart e n ka, C. N e lkow s ki. Wstęp J. Kańs ki. Bydgoszcz 1993, s. 19. - The Harvard Concise Dictionary of Music and Musicians. Ed. D. M. Rande1. Cambridge 1999, s. 31. Sh. M. Ke en er w artykule Virtue, Illusion, Venezianità: Vocal Bravura and the Early Cortigiana Onesta (w: Musical Voices of Early Modern Women: Many-Headed Melodies. Ed. Th. La May. London, b. r.) zwraca uwage na to, że 
za trop kluczowy w rozszyfrowywaniu indywidualnych cech tajemniczej melodii z Taczki occiarza, ponieważ określenie to, dodane do tytułu pieśni czy piosenki, wskazywało jedynie na jej genealogię albo przynależność gatunkową.

Ustalenie muzycznego pierwowzoru „Wenecjanki” okazało się możliwe dzięki porównaniu zachowanych publikacji nutowych z początku XIX wieku z obu już przywołanymi zapisami nutowymi, które przypisywane sa piosnce Starego Dominika. Założyłam, iż w historycznych drukach muzycznych z pierwszej połowy wieku XIX nadal powinna się odwzorowywać przyjęta przez Bogusławskiego zasada tak częsta w XVIII-wiecznych operach buffa, najpopularniejszej w Europie formie scenicznej tamtego czasu - że ta sama piosenka czy aria może być wszczepiana do utworów scenicznych różnego autorstwa na zasadzie słowno-muzycznego cytatu, parafrazy lub kontrafaktury. Od takiej praktyki nie uchylali się nawet najbardziej ambitni XVIII-wieczni autorzy oper - np. oklaskiwana w 1710 roku londyńska nowość, wykorzystująca czarny humor Agryppina Georga Friedricha Haendla, zawierała aż 40 numerów zapożyczonych, i to nie tylko z wcześniejszej twórczości scenicznej samego kompozytora, ale też od Reinharda Keisera czy od Johanna Matthesona, który otwarcie oprotestował takie zawłaszczenie ${ }^{16}$. Choć biograf Haendla objaśnia, iż powroty kompozytora do już wykorzystanej materii operowej przytrafiały się młodemu muzykowi dlatego, że ten dopiero poszukiwał własnych, oryginalnych rozwiązań wśród obowiązujących wzorców ${ }^{17}$, to jednak nie można zlekceważyć czynnika praktycznego: numery sceniczne, które sprawdziły się przed publicznością, chętnie wszczepiano do innych sztuk, aby zagwarantować takim spektaklom powodzenie. Do wcześniej napisanego libretta można było dołączyć popularne arie tego samego kompozytora lub innych twórców muzyki teatralnej, ale można też było podnieść atrakcyjność nie libretta czy muzyki, tylko wykonania wokalnego. To z tego powodu Wolfgang Amadeus Mozart w roku 1789, specjalnie dla panny Louise Villeneuve, skomponował dwie arie, włączone do wypróbowanej scenicznie w 1786 roku sztuki Il burberodi buon cuore, której libretto skroił Carlo Goldoni i do której muzykę napisał Vicente Martín y Soler ${ }^{18}$. Można było wykorzystać mechanizm pasticcios, sztuk montowanych $z$ dawnych numerów muzycznych różnego autorstwa, osadzanych na ossaturze nowego libretta - praktyki niezbyt cenionej, ale pozwalającej w krótkim czasie przygotować nowe widowisko bez zaciagania zobowiązań wobec konkretnego kompozytora, a przy tym skracającej czas prób (śpiewacy najczęściej dobrze już znali wybrane partie solowe, duety i ensem-

model śpiewania arii veneziana, uznany za przejaw weneckiego patriotyzmu, można wywieść z czasów, gdy mianem tym określano styl wykonywania utworów słowno-muzycznych przez weneckie kurtyzany (w XV-XVI w. utwory te zwano cortigiana onesta).

Aria napoletana (neapolitańska) wykształciła się jako trzyczęściowy utwór o strukturze ABA (aria da capo) pod koniec XVII w. jako jedna $\mathrm{z}$ form charakterystycznych dla szkoły neapolitańskiej. Zob. Habela, op. cit., s. 17-18, 124-125.

16 Zob. Ch. Hog wo o d, Händel. Przeł. B. Świders ka. Kraków 2009, s. 54-55.

17 Ibidem, s. 55.

18 Była to opera - dramma giocoso w dwu aktach - wystawiona 4 I 1786 w wiedeńskim Burgtheater. Arie sopranowe W. A. M o za r ta: Chi sà, chi sà, qual sia, KV 582; Vado, ma dove?, KV 583. Zob. P. Ka mińs ki, Tysiąc i jedna opera. T. 1. Kraków 2008, s. 843. - „L'Almanacco di Gherardo Casaglia”. Na stronie: http://almanac-gherardo-casaglia.com/index.php?Testo=Il_burbero_di_ buon_cuore\&Parola=Stringa (data dostępu: 11 IX 2019). 
ble). Wystarczy przejrzeć uważnie A General History of Music czy Obecny stan muzyki we Francji i Italii Charlesa Burneya, by przekonać się, jak często w XVIII-wiecznych operach europejskich stosowano pasticcio ${ }^{19}$. Hybrydyczność i zmienność struktury XVIII-wiecznych oper buffa wynikała nie tylko z podanych przyczyn pragmatycznych, ale również z powolnego krystalizowania się budowy formalnej tego typu opery, poszukującej sposobów zintegrowania fabuły z numerami śpiewanymi. Brak skrępowania regułami dramaturgicznymi właściwymi operze seria a więc przyzwolenie na pewna swobodę - doprowadził do pojawienia się w operze buffa tematyki mieszczańskiej i ludowej. W ten sposób dotychczasowy krąg odbiorców poszerzył się o widzów ze średnich i niższych warstw społecznych, a motywy i tematy typowe dla farsy, komedii mieszczańskiej, satyry obyczajowej, comédie larmoyante i baśni zaczęły się asymilować, co pozwało wypróbowywać zróżnicowane chwyty sceniczne ${ }^{20}$.

Doświadczeni libreciści i kompozytorzy wiedzieli, że aby zdobyć publiczność teatru muzycznego, dobrze jest włączać do swoich dzieł chwytliwe arie, które mimochodem zapiszą się w pamięci widzów. Potwierdzają to słowa Lorenza Da Ponte. Znalazłszy się na początku XIX wieku w Nowym Jorku, przemyśliwał on nad tym, w jaki sposób artysta ze Starego Kontynentu może sobie zjednać obcą publiczność. Według niego powinna sprawdzić się znana europejska praktyka. Artysta musi zaopatrzyć się w „spory zasób arii i tak zwanych pezzi concertati o łatwej, naturalnej i śpiewnej melodii, acz nie pospolitej ani prostackiej”.

Pozostają one łatwo w uchu i sercu słuchacza, nuca je amatorzy wychodząc $z$ teatru, wydawcy prześcigają się w wydawaniu ich; gdy są wydane, kupuja je i śpiewają tak ci, co umieją śpiewać, jak i ci, co nie umieją, wracają po wielokroć do teatru, by je znowu usłyszeć; niekiedy dwa lub trzy fragmenty tego rodzaju wystarczają, aby opera się podobała, $\mathrm{z}$ honorem dla śpiewaka, $\mathrm{z}$ chwałą dla kompozytora i, co najważniejsze, $z$ prawdziwą korzyścią dla przedsiębiorcy ${ }^{21}$.

Z opisanej reguły korzystano oczywiście już wcześniej, tzn. w okresie, gdy włoska opera podbijała teatry Paryża, Londynu, Wiednia i Warszawy, a jej popularność była tak duża, że zwolennicy oper narodowych coraz odważniej występowali przeciwko jej wpływom, postulując wyzwolenie $\mathrm{z}$,włoskiej niewoli” czy - jak w latach dziewięćdziesiątych XVIII wieku uczynił Bogusławski - podejmując próbę przygotowania narodowego zespołu, aby „się [...] przeciwko przemocy włoskich oper zapewnić" 22 . Kontestatorzy włoskiej ekspansji kulturowej występowali m.in. przeciwko coraz popularniejszemu w operze stylowi buffa, inicjując spór - znany jako „Querelle des Bouffons” - który w latach pięćdziesiątych XVIII wieku roznamiętnił umysły zarówno zwolenników, jak i wrogów ${ }^{23}$. Refleks tamtej dyskusji odnajdziemy choćby w korespondencji starosty przemyskiego Stanisława Antoniego Poniatow-

Ch. Burn ey: A General History of Music: From the Earliest Ages to the Present Period. T. 4. London 1789; Obecny stan muzyki we Francji i Italii, albo Dziennik podróży przez owe kraje, podjętej celem zebrania materiałów dla „Powszechnej historii muzyki”. Przekł., oprac., wstęp J. C h a c h u ls ki. Warszawa 2017. XVIII wieku. T. 1. Kraków 2008, s. 451.

21 L. Da Ponte, Pamiętniki. Przeł. J. Popiel. Wyd. 2. Kraków 1987, s. 473-474.

22 Hogwood, op. cit., s. 122. - Bogusław s ki, Dzieje Teatru Narodowego [...], s. 66.

23 Zob. La „Querelle des Bouffons” dans la vie culturelle française du XVIIIe siècle. Textes réunis et http://rcin.org.pl 
skiego, który „buffonistów” nazywa z przekąsem „sektą" ${ }^{4}$. Niezależnie jednak od tych napięć, europejskie teatry nadal zapraszały librecistów, kompozytorów, śpiewaków i antreprenerów włoskich, stopniowo przejmując operowy repertuar scen weneckich czy neapolitańskich i chętnie wzorując się na włoskim bel canto. Jak się wydaje, historia „Wenecjanki” jest dość istotnym elementem owej opowieści o podboju XVIII-wiecznych europejskich teatrów przez kulturę muzyczną Italii.

Założyłam wstępnie, że przypadek włączenia weneckiej arii do spolszczonego tekstu sztuki francuskiej nie mógł być wyjątkowym zjawiskiem wyemancypowania się słynnej włoskiej melodii i opuszczenia przez nia terenu rodzimej opery. XIX-wieczne druki muzyczne rejestrujące „Wenecjankę” dają retrospektywny wgląd w proces osmotycznego przenoszenia komponentów sztuki włoskiej do XVIII-wiecznej kultury francuskiej, angielskiej czy polskiej, choć trzeba podkreślić, że jest to wiedza fragmentaryczna i nadal niekompletna.

Temat muzyczny „Wenecjanki”, znany ze spektaklu Bogusławskiego, odnajdujemy w XIX-wiecznych opracowaniach muzycznych weneckiej arii La mia crudel tiranna ${ }^{25}$, włączonej do dwu oświeceniowych oper: do wystawianego w latach dziewięćdziesiątych XVIII wieku w Warszawie (zarówno w oryginale ${ }^{26}$, jak i w tłumaczeniu Bogusławskiego ${ }^{27}$ ), a mającego swą premiere 17 XI 1789 w Wiedniu, dramma giocoso zatytułowanego Una cosa rara, ossia Bellezza ed onestà ${ }^{28}$ (Piękność

présentés par A. F a bi a n o. Paris 2005. - C. D a u p h in, La Querelle des Bouffons: crise du goût musical et scission du royaume sous Louis XV. „Synergies Espagne” 4 (2011).

Cyt. za: Z. C h a n i e c k i, Europejskie teatry lat 1750-1815 w relacjach polskich podróżników. Łódź 2019, s. 175.

Aria della "Cosa rara”, cantata dal signor Nozari, avec accompagnement de piano et des paroles françaises. [Kompozytor: V. Martín y Sole r]. Paris [1800]. - La mia crudel tiranna: The Much Admired Venetian Air, as Sung in the Opera of „Le due nozze e un sol marito” [by P. C. Guglielmi]. With variations composed by F. A. Radicati. London 1815. (Oryginał w: The British Library. Zob. na stronie: https://books.google.pl/books?id=GSfzt5PW2vYC\&pg=PP3\&lpg=PP3\&dq=La+mi a+crudel+trianna+.. 〈data dostępu: 11 IX 2019〉. Choć F. A. Radicati umieszczony jest na karcie tytułowej jako autor utworu, to trzeba wprowadzić sprostowanie, że jest on tylko muzykiem, który zaaranżował utwór na głos, harfę i fortepian). Słowa weneckiej arii La mia crudel tiranna - zob. aneks II 1.

26 Według Bernackiego (op. cit., t. 2, s. 218) Cosa rara została wystawiona w wersji włoskiej na warszawskiej scenie publicznej 3 i 30 I oraz 20 II 1790, gdzie zaprezentowała ją trupa D. Guardasoniego (zob. Raszewski, Bogusławski, t. 1, s. 277. - Kamiński, op. cit., t. 1, s. 843). Niewątpliwie sztuka ta była jedna z najpopularniejszych oper przed zawłaszczeniem scen muzycznych przez G. Rossiniego i prawdopodobnie dlatego muzyczny cytat z Cosa rara znalazł się w finałowej scenie aktu II Don Giovanniego W. A. Mozarta. A. B a t a (Co się tańczy, je, pije i jak się muzykuje w „Don Giovannim”? W zb.: Opera. Kompozytorzy, dzieła, wykonawcy. Red. ... Köln 2001, s. 384) skomentował to następująco: „U tak wielkiego pana jak Don Giovanni gra się naturalnie najnowsze szlagiery operowe”. Zob. też Ka miń s ki, op. cit., t. 1, s. 843.

Przekład Bogusławskiego sztuki Cosa rara wystawiono 17 I 1794 w Warszawie, wedle zachowanego plakatu pod tytułem Piękność z uczciwościa - rzecz rzadka (zob. na stronie: https://www.koszykowa.pl/skarby/3524-pieknosc-z-uczciwoscia-rzecz-rzadka-afisz-teatralny-z-1794-r 〈data dostępu: 11 IX 2019〉). Sam Bogusławski (Dzieje Teatru Narodowego [...], s. 76), grajacy w sztuce Lubina, używał skróconego jej tytułu, o czym świadczy taki oto fragment: „przetłumaczyłem więc drugą z ulubionych dawniej oper, Rzecz rzadka, po włosku Cosa rara zwaną. Zabawna ta sztuka przyjemną okraszona muzyką nie mniej podobała się jak pierwsza [tj. Axur, król Ormus]”. Libretto: L. D a P o n te, Una cosa rara, ossia Bellezza ed onestà. Dramma giocoso per musica, da 
z uczciwościa - rzecz rzadka ${ }^{29}$ ), autorstwa Lorenza Da Ponte ${ }^{30}$, z muzyką hiszpańskiego kompozytora Vicente Martína y Solera, oraz do opery Due nozze e un sol marito, $\mathrm{z}$ muzyka Pietra Carla Guglielmiego i z dwuaktowym librettem nieznanego autorstwa, przedstawionej włoskiej publiczności po raz pierwszy we florenckiej Accademia degli Infuocati w 1800 roku $^{31}$. Ponieważ dokumenty przypisują tę samą melodię dwóm różnym kompozytorom, wydaje się nader prawdopodobne, że żaden z owych kompozytorów nie jest autorem „Wenecjanki”. Można też przewidzieć, iż poszukiwania doprowadza do odkrycia kolejnego mniemanego autorstwa, co potwierdzi, że utwór ten był szczepiony na różnych librettach operowych z zamiarem związania uwagi publiczności znanym tematem muzycznym.

Trzeci trop prowadzi do cyfrowej edycji The Italian Opera Aria on the London Stage, 1705-1801, przygotowanej pod kierunkiem Michaela Burdena, historyka opery angielskiej XVII-XIX wieku, a współtworzonej przez muzykologa Christophera Chowrimootoo ${ }^{32}$. W przedstawionym tam wykazie sztuk - powstałym na pod-

rappresentrasi nel magnifico Teatro dell'Accademia Filarmonica di Verona nella primavera 1788. Dedicata [...] Alvise 5. Sebastiano K.r Mocenigo podesta e vice capitanio. Bibl. Nazionale Braidense w Mediolanie, sygn. IT-MI0185. Zob. na stronach: http://www.bibliotecamusica.it/cmbm/viewschedatwbca.asp?path=/cmbm/images/ripro/libretti/02/Lo02868; http://www.librettidopera.it/ cosarara/cosarara.html (daty dostępu: 11 IX 2019).

Es tre i ch er zapisał inny wariant tytułu: Rzecz rzadka, czyli Piękność złaczona z cnota (podaję za: Bernacki, op. cit., t. 2, s. 219).

Podstawę libretta znalazł Da P o n te w komedii L. Véleza de Guevary La luna de la Sierra (Księżyc Sierry), w Pamiętnikach (s. 142-146, 170) odnotował, że choć Cosa rara stanowiła efekt bardzo spójnej współpracy librecisty i kompozytora, to zespół śpiewaków mających brać udział w premierze oprotestował jakość muzyki tej opery. Instancją rozstrzygającą spór był cesarz, dzięki któremu nie tylko doszło do premiery Rarytasa, ale też Da Ponte otrzymał kolejne zlecenie, a Martín y Soler - zaproszenie Katarzyny II do Petersburga.

31 Potwierdzenie, że nie ma mowy o błędnym przyporządkowaniu arii do utworu scenicznego, znajdujemy w dwu publikacjach. T. J. W als h (Opera in Dublin, 1798-1820: Frederick Jones and the Crow Street Theatre. Oxford 1993, s. 119) odnotowuje, że 22 VIII 1811 T. Bertinotti zaśpiewała arię La mia crudel tiranna w akcie I Le due nozzi i że akompaniował jej na gitarze mąż; J. C. G ree n (Theatre in Dublin, 1745-1820: A Calendar of Performances. T. 5. Bethléem 2011, s. 3867) dodaje, że przedstawienie było benefisem tenora C. Cauviniego, że dyrygował orkiestrą D. Corri, pierwszym skrzypkiem był F. Radicati, mąż sopranistki, a spektakl powtórzono 7 IX 1811.

Natomiast w żadnym ze znanych mi manuskryptów muzycznych tej opery (pierwszy - z ok. 1810 r. dostępny jest w Badische Landesbibliothek Karlsruhe 〈zob. na stronie: https://digital.blb-karlsruhe.de/blbihd/content/titleinfo/3976425 [data dostępu: 11 IX 2019] ); drugi - z 1801-1810 r. w bazie Gallica, $\mathrm{BnF}$ (wskazanych jest dwu kompozytorów: obok P. C. Guglielmiego także L. Caruso〉) ani w żadnym $z$ librett (dramma giocoso per musica - wersja florencka $\mathrm{z}$ r. 1800, oryginał w: Biblioteca Nazionale Centrale di Roma; wersja turyńska z r. 1812, podstawy spektaklu ocenionego ze względu na niedoskonałości realizacyjne nader surowo przez „Courrier de Turin. Journal politique, littéraire etc." 〈1812, nr 136, z 4 X, s. 556)) nie znalazłam śladów tej amplifikacji muzycznej. Jak podaja F. Clément i P. La rous s e (Dictionnaire lyrique, ou Histoire des opéras. Genève 1999, s. 240), sztuka ta miała premierę wcześniej - już w 1774 r. w Neapolu. W prowadzonej przez londyński periodyk „The Harmonicon” (1830, s. 71) kronice wystawień włoskich oper w Anglii odnotowano, że oczekiwany przez londyńczyków G. Naldi, basso caricato, niezbyt udanie zadebiutował w kwietniu 1806 w słabej operze Due nozze e un sol marito Guglielmiego, w związku z czym kompozytora uznano za bezbarwnego i "niedochodowego” (krytyczna ocena tego dawniej cenionego twórcy świadczy o stopniowej zmianie gustów operowych w Europie). 
stawie analizy drukowanych i rękopiśmiennych librett w języku włoskim, na których kanwie wystawiano w Londynie w latach 1705-1801 spektakle operowe - umiejscowiono w każdej inscenizacji poszczególne arie, przyporządkowując im twórców i wykonawców, co pozwala prześledzić, jak poszczególne partie śpiewane, za sprawą decyzji impresariów, dyrygentów i śpiewaków, migrowały pomiędzy różnymi wersjami tego samego libretta, opracowywanego na nowo dla poszczególnych teatrów, albo jak wędrowały pomiędzy librettami różnych autorów. W przypadku interesującej nas „Wenecjanki” Burden wskazuje, że aria ta wykonywana była wraz z librettem dramma comico per musica Carla Goldoniego i Vincenza Legrenzia Ciampiego ${ }^{33}$ Il negligente ${ }^{34} \mathrm{w}$ czasie londyńskiej premiery tej sztuki, w 1749 roku, jako dwudziesty numer solowy w scenie 6 aktu III i że śpiewał ją Pasquino, sługa bogatego a zaniedbującego własne sprawy Filiberta ${ }^{35}$. Analizująca libretto Il negligente Gabriella King zwraca uwagę na to, że w kroju bohaterów tego dramma giocoso per musica łatwo dostrzec powtórzenie włoskiego wzoru z commedia dell'arte: para amantów wywodząca się $z$ wyższych sfer poprowadzona jest serio, a - na zasadzie kontrastu - w tonie buffo toczą się dialogi przypominających Arlekina i Colombinę służących: Pasquina i Porporiny, którzy w scenie 6 parodiują model miłości dworskiej. W tym kontekście miękka kantylena „Wenecjanki” i jej melodramatyczne słowa o tyranii miłości, podszytej zazdrością i bólem niepewności, zyskują wymowę ironiczną ${ }^{36}$.

www.italianopera.org/compositori/C/c217633F.htm (data dostępu: 14 IX 2019). Porządkowaniu bogatego materiału dotyczącego londyńskich realizacji operowych z lat 1711-1844 poświęcił M. B u r d en 5-tomowa edycję London Opera Observed (London 2013).

P. Ris t a (At the Origins of Classical Opera: Carlo Goldoni and the Dramma Giocoso per Musica. Bern 2018, s. 32), której badania porównawcze koncentrują się na rozpoznawaniu związków literatury i muzyki w teatrze włoskim, zaznacza, że Goldoni niezwykle często współpracował z muzykami neapolitańskimi i że choć Ciampi nie urodził się w Neapolu, to jednak kształcił się tam od najmłodszych lat i w pełni uformował swój muzyczny styl pod wpływem estetyki neapolitańskiej.

Ani w wykazach B erna cki e go (op. cit., t. 2), ani w książce J. Łu ka s ze wi c z (Carlo Goldoni $w$ polskim oświeceniu. Wrocław 1997) nie znalazłam potwierdzenia, by sztuka ta była wykonywana przed polską publicznością.

Porównanie kolejnych wariantów realizacji librett, począwszy od tego zaprezentowanego w Wenecji w Teatro Giustinan di San Moisè jesienią 1749, przez kolejne, opublikowane w Parmie (1752), we Florencji (1752), w Lejdzie (1752), znowu w Wenecji (1753), w Trieście (1756), a skończywszy na weneckiej publikacji libretta $\mathrm{z}$ r. 1795, nie wskazuje na przynależność arii La mia crudel tiranna do drukowanego tekstu podstawowego. Nie znajdziemy też „Wenecjanki” w indeksie arii dołączonym do libretta opracowanego na podstawie wersji z 1749 r. (zob. na stronie: http://www.librettidopera.it/zps_gol/Z_pdf/023\%20Negligente.pdf, s. 52 (data dostępu: 13 IX 2019〉), co sugeruje, że La mia crudel tiranna wprowadzono jako dodatkową atrakcję wokalną dopiero w wersji londyńskiej. Realizatorzy projektu Varianti all'opera (zob. na stronie: http://www.variantiallopera.it/public (data dostępu: 12 X 2019〉), konsolidującego badaczy z uniwersytetów w Padwie, w Mediolanie i w Sienie (A. L. Bellina, A. Chegai, G. Polin, C. Toscani), uprzystępniają do analizy komparatystycznej warianty librett realizowanych na scenach europejskich $\mathrm{w}$ w. XVIII, przy czym koncentrują się na czterech twórcach: C. Goldonim, N. Jommellim, P. Metastasiu i G. B. Pergolesim. Zob. też Catalog of Opera Librettos Printed Before 1800. Prepared by O. G. Th. S o n n e ck. T. 1. Washington 1914, s. 787-788. - Jw., t. 2, s. 1280.

35 Zob. na stronie: http://italianaria.bodleian.ox.ac.uk/result.php?task=record\&offset=0\&rec=9652 (data dostępu: 15 IX 2019).

36 G. King, Carlo Goldoni and the $18^{\text {th }}$-century London Stage, s. 38-40. Na stronie: https://core. ac.uk/download/pdf/78865317.pdf (data dostępu: 15 IX 2019). Il negligente był to utwór powsta- 
W roku 1750 sztuka Il Negligente została przeniesiona ze sceny Little Theatre do King's Theatre, gdzie spektakl powtórzono dwukrotnie. Nie był to fortunny czas dla włoskiej trupy i repertuaru buffo - choćby z tego względu, że zarządzanie ekscentrycznego dr. Johna Francesca Crosa doprowadziło do bankructwa teatru, do uwięzienia dyrektora i do zamknięcia opery na kolejne trzy lata ${ }^{37}$. Może należałoby ograniczyć komentarz na temat tej burletty ${ }^{38}$ do przywołania stwierdzenia badaczy, że przeszła ona przez scenę londyńską niezauważona, i odnotować zgryźliwy komentarz brytyjskiego aktora Colleya Cibbera, który przewidywał, że sztuka ta - jak chora roślina - umrze, zanim zapuści korzenie ${ }^{39}$, gdyby nie relacja Burneya, który przypomniał, że to w tym spektaklu wcielający się w rolę Pasquina ${ }^{40}$ tenor wirtuoz Filippo Laschi ${ }^{41}$ wykonał czarująco arię La mia crudel tiranna, budzącą zawsze aplauz publiczności ${ }^{42}$.

ły na rok przed Teatrem komediowym, w którym Goldoni zamanifestował potrzebę reformy teatru, ale - jak podkreśla King (ibidem, s. 41) - już w tym utworze wdrożył zasady postulowane później. Zob. S. Will a ert, Italian Comic Opera in London 1760-1770, s. 11. Na stronie: https://www. researchgate.net/publication/299967743 (data dostępu: 14 IX 2019). Zob. też Kin g, op. cit., s. 30. W drugiej połowie XVIII i na początku XIX w. w Anglii określano tym terminem włoską operę komiczną, często parodystycznie traktującą tematykę i konwencje opery seria; używał tego terminu i opisywał przykłady utworów tej odmiany jeden z pierwszych muzycznych historiografów B u r n ey (A General History of Music, s. 129; Obecny stan muzyki we Francji i Italii, s. 148, przypis 187), przyznając, że póki Anglia nie poznała oper komicznych Latilli, Ciampiego i Galuppiego, niewiele wiedziano o specyfice burletty. Zob. King, op. cit., s. 30. - J a c o b s, op. cit., s. 49.

Świadomość odrębności tej odmiany utworów operowych poświadcza osobliwy dokument: A Letter to the Author of the Burletta Called Hero and Leander: In Refutation of What He Has Advanced in His Dedication to Philips Glover, Esq. on the Statutes for the Regulation of Theatres, the Conduct of Mr. Palmer, of Mr. Justice Staples, and the Other Justices; and Also of His Observations on the [...] Establishment of a Theatre in Wellclose Square (London 1787). Jego autor próbuje przekonać czytelnika, że zarówno burletty, jak i widowiska pantomimiczne powinny podlegać cenzurze Lorda Szambelana, ponieważ mogą one wpływać niekorzystnie na moralność społeczeństwa.

39 Zob. S. Willa e r t: Goldoni's Comic Operas in London in the 1760s: Relations Between an Italian Genre and a London Audience. 2009, s. 1. Na stronie: https://www.researchgate.net/publication/317955899_Goldoni's_Comic_Operas_in_London_in_the_1760s_Relations_Between_an_Italian_Genre_and_a_London_Audience_appeared_in_Italian_in_2009_(data dostępu: 14 IX 2019); Le opera comiche del Goldoni nella Londra del 1760: il apporto tra un genere italiano e un pubblico inglese. „Atti del Convegno” 14 (2009): Goldoni, la musica, la scena, l'Europa. Problemi di critica goldoniana, s. 267.

40 Według rejestru B u r d e n a - zob. na stronie: http://italianaria.bodleian.ox.ac.uk/result.php?task=record\&offset=0\&rec=9653 (data dostępu: 15 IX 2019).

41 Filippo Laschi (1738-1789; jego nazwisko pisano też: Larschi lub Larchi) - tenor włoski wspominany z podziwem nie tylko przez Burneya, ale też przez W. A. Mozarta czy G. Casanovę; choć kariere śpiewaka rozpoczął od ról serio, to jego żywiołem stała się opera buffa, występował właśnie w takim repertuarze w Londynie (1748-1750), w Brukseli (1749), w Amsterdamie (1750), w Wiedniu (1765-1768) - do jego ważnych dokonań należy zaliczyć występy w licznych komediach per musica Goldoniego; w latach siedemdziesiątych XVIII w. uczył takich śpiewaków, jak bas L. Bassi czy tenor M. Kelly; był również autorem arii śpiewanych w pasticcios (np. The Maid of the Mill, 1765) - biogram w: The Grove Book of Opera Singers. Ed. L. Willi a m s M a cy. Oxford 2008, s. 269 (autorzy hasła: R. G. King, F. Pi perno, S. Willa er t). Śpiewane przez niego arie bywały wydawane w odrębnych zbiorach, np. The Favourite Songs in the Opera call'd Li Tre cicisbei ridicoli. [Score] (London 1749). Zob. A. Ch o r o n, F. F a y oll e, Dictionnaire historique de musiciens artistes et amateurs, morts ou vivans. Paris 1817, s. 402. 
Czy występując od 22 IX 1765 do 22 III 1767 na dworze hetmana Jana Klemensa Branickiego w Białymstoku, a także gościnnie na królewskim dworze Stanisława Augusta Poniatowskiego w 1766 roku, Laschi zaprezentował polskiej publiczności tę piękną wenecką arię? Czy to ona przyczyniła się w jakimś stopniu do tego, że przez warszawskich aktorów był „wynoszony pod niebiosa” ${ }^{43}$ ? Czy mogła być włączona do wystawionego wiosna $1766 \mathrm{w}$ białostockim teatrze Il cavaliere per amore, dwuczęściowego intermezza, azione comica ${ }^{44}$ spółki Giuseppe Petrosellini Niccolò Piccini, w którym to spektaklu Laschi kreował rolę Florinda, a może była wykonana w czasie koncertu? ${ }^{45}$ Nie jest to nieprawdopodobne.

Nadal otwarte pozostaje pytanie, czy to Ciampi był autorem melodii - nie natrafiłam na dokumenty i publikacje, które by to poświadczały. Poza tym w jednym $\mathrm{z}$ francuskich XIX-wiecznych zbiorów pieśni, Le Chansonnier des Graces. Avec la musique gravée des airs nouveaux ${ }^{46}$, gdzie osobno podano słowa „Wenecjanki” wraz

tach wspominał Ch. Burney po wielu latach i w polemice $\mathrm{z}$ J. J. Lefrançois de Lalande'em (Voyage d'un François en Italie, fait dans les années 1765 \& 1766: contenant l'historie \& les anecdotes les plus singulières de l'Italie, \& sa description, les mours, les usages, le gouvernement, le commerce, la littérature, les arts, l'histoire naturelle \& les antiquités, avec des jugemens sur les ouvrages de peinture, sculpture \& architecture, \& les plans de toutes les grandes villes d'Italie. Venise [1769]). Próbował on wykazać, że aktorzy włoscy jeśli potrafią śpiewać, to nie potrafia grać. B u r n e y (Obecny stan muzyki we Francji i Włoszech, s. 437) przywoływał właśnie tych dwu śpiewaków jako przykład spójnego łączenia umiejętności wokalnych $z$ aktorskimi przez artystów pochodzących z Italii. Zob. też Ch. B u r n ey, De l'état présent de la musique en France et en Italie, dans les Pays-Bas, en Hollande et en Allemagne, ou Journal de voyages faits dans ces différens pays avec l'intention d'y recueillir des matériaux pour servir à une histoire générale de la musique. Trad. Ch. Brack. Gênes 1809-1810, s. 293.

43 W. J a ku bow s ki, list do J. K. Branickiego. W zb.: Teatr Narodowy 1765-1794. Red. J. Ko tt. Warszawa 1967, s. 643.

44 A. Żórawska-Witkow ska (Muzyka na dworze Jana Klemensa Branickiego. W zb.: Dwory magnackie w XVIII wieku. Red. T. Kostkiewiczowa, A. Roćko. Warszawa 2005, s. 239), opisując repertuar wystawiany w latach sześćdziesiątych XVIII w. na dworze J. K. Branickiego w Białymstoku, zwraca uwagę na to, że sztuka ta miała dwie wersje. Wersja starsza, krótsza, były to właśnie intermezza, które przekształciły się w utwór dłuższy i bardziej rozbudowany (dla 7 śpiewaków).

W zachowanych librettach z epoki widoczna jest pewna dowolność w klasyfikowaniu tego utworu: w wydaniu wiedeńskim [1766?] (Digitale Library of Congress, Control Number 2010664664) oraz w drezdeńskim - włosko-niemieckim - wydaniu tej sztuki z 1766 r. (jw., Control Number 2010664665) znajdujemy wskazanie, że jest to azione comica per musica; w wersji bolońskiej z 1763 r. (Digitale Biblioteca Nazionale Centrale di Roma) oraz lizbońskiej z 1764 r. (Digitale Sammlungen der Universitätsbibliothek Bayreuth) - farsetta; w druku turyńskim z 1762 r. - opera buffa (Biblioteca Digitale Italiana); na karcie tytułowej wersji wydanej w Pizie, podobnie jak we włosko-duńskiej wersji z Kopenhagi z 1769 r. (Library of Congress, Control Number 2010664543), widnieje nazwa: dramma giocoso in musica.

45 Występy na scenie białostockiej Laschiego, „virtuoso di camera di S. A. Reale il Principe Carlo ddi Corena, Duca di Bar", poświadcza nie tylko B e r n a c ki (op. cit., t. 2, s. 214). Białostocki fragment tej trwającej 50 lat kariery scenicznej włoskiego tenora został omówiony w rozprawie Żórawski j - Witkowskiej (op. cit., s. 238-239). Zob. też I. Kulesza - W or o ni e cka, Cudzoziemcy $w$ Białymstoku $w$ XVIII wieku. „Studia Podlaskie” 19 (2011), s. 147.

46 Była to seria śpiewników wydawana w Paryżu w latach 1796-1848 pod wspólnym tytułem Le Chansonnier des Graces. Avec la musique gravée des airs nouveaux. Zob. edycję z r. 1808 (s. 225 $\langle$ słowa〉; dodatek nutowy - s. $25\langle\mathrm{nr} 35\rangle$ ). 
z tzw. prymką, pozwalająca rozpoznać linię melodyczną utworu tak lubianego przez warszawską publiczność Teatru Narodowego w latach dziewięćdziesiątych wieku XVIII, wskazano na innego kompozytora niż Ciampi. Pod tytułem canzonetty ${ }^{47}$ widnieje dopisek: „Musica per Signor Bianchi” ${ }^{48}$. Kuszacy jest pomysł, by uznać tę melodię za stworzoną przez pierwszego gondoliera-poetę Antonia Bianchiego ${ }^{49}$, ale on pisał przede wszystkim poematy heroiczne i heroikomiczne, muzykę zaś do jego dramatów muzycznych komponowali inni (A. Boroni, G. Latilla). Jednakże równie dobrze - zwłaszcza że temat jest nieco przetworzony w stosunku do wcześniej przedstawionych wersji muzycznego zapisu ${ }^{50}$, a zbiór wydano w roku 1808 - może to być ścieżka prowadząca do kompozytora, który zmienił pierwotną wersję: może był to słynny kompozytor Francesco Bianchi ${ }^{51}$ ? Na tym etapie badań sprawa autorstwa „Wenecjanki” musi pozostać nierozstrzygnięta - na pewno wiemy, że ten temat muzyczny powstał nie później niż w 1749 roku.

\section{Wariacje na temat „Wenecjanki”}

Wskazane przeze mnie wyciągi muzyczne tej samej arii pochodzącej z dwu różnych oper mają charakter aranżacji na głos i towarzyszace mu instrumenty i opracowane są dla konkretnych włoskich wykonawców: dla Andrei Nozzariego, nazywanego „ojcem tenorów” wybitnego odtwórcy ról w operach Rossiniego, oraz dla Teresy Bertinotti-Radicati, świetnej sopranistki o światowej sławie ${ }^{52}$. Z takiego zapisu

La mia crudel tiranna kwalifikowano jako a rię (pieśń solową z akompaniamentem orkiestry, wykonywaną w operze, oratorium, kantacie), a ri e t tę (tzw. małą arię, o pogodnym, lekkim charakterze, często o budowie dwuczęściowej, w XVIII w. przyjmującej formę ronda) lub c a n z o n e ttę (krótką pieśń solową o włoskiej proweniencji, często nie mającą związku z operą). Zob. Ha b ela, op. cit., s. 17-18, 33. - J a c o b s, op. cit., s. 19, 55.

48 Le Chansonnier des Graces (1808), s. 225. To jedyny znany mi dokument, który poświadcza, że Bianchi jest autorem melodii La mia crudel tiranna.

49 Antonio Bianchi (ur. między 1700 a 1720, zm. ?) - autor m.in. poematu Davide re d'Israele. Poema eroico sagro di A. B. servitore di gondola veneziano (1751) oraz oratorium dramatycznego Elia sul Carmelo, Le villeggiatrici ridicol, drama giocoso per musica czy L'Oridegno, o sia la Cuccagna conquistata, poema eroicomico di Antonio Bianchi (1759). Zob. Biographie universelle ancienne et moderne. T. 4. Paris 1843, s. 268. - Biographie universelle des hommes qui se sont fait un nim. Oprac. F.-X. F ell er. T. 3. Nevers 1845, s. 381. - Dizionario biografico degli Italiani. T. 10. [Roma] 1968 (autor hasła: G. F. T o r c ell a n). - Na stronie: http://www.treccani.it/enciclopedia/antonio-bianchi_res-0df42abb-87e8-11dc-8e9d 0016357eee51_(data dostępu: 11 IX 2019).

Zob. aneks I 5.

51 Należałoby w przyszłości przestudiować pod kątem autorstwa melodii La mia crudel tiranna twórczość Francesca Bianchiego (1752-1810), włoskiego kompozytora, w latach 1785-1791 i 1793-1797 organisty w bazylice św. Marka w Wenecji, autora oratoriów religijnych Gioas, re de Giuda, Agar Fugiens, Abramo et Isacco oraz oper wystawianych nie tylko w Italii, ale też w Londynie i w Paryżu - np. La Zemira, La villanella rapita, La vendetta di Nino, o sia Semiramide, La Famille vénitienne, ou Le Château d'Orsen (zob. „Mercure de France. Journal littéraire et politique” 1811, $\mathrm{nr}$ 48, s. 467. - Biographie universelle ancienne et moderne, s. 268-269. - Baker's Biographical Dictionary of Musicians. Ed. N. Slonim sky, G. Schirm er. New York 1958, s. 150).

52 Andrea Nozzari lub Nosari (1776-1832) - pochodzacy z Bergamo śpiewak o osobliwym rejestrze wokalnym: mógł śpiewać partie tenorowe i barytonowe; pierwotnie występował w mediolańskiej La Scali, w latach 1803-1806 był zatrudniony w Théâtre Italien w Paryżu, po powrocie wzmocnił swoją pozycję w świecie operowym dzięki współpracy z G. Rossinim (1815 - Elisabetta 
można wnioskować, że pieśń La mia crudel tiranna mogła być prezentowana w ramach europejskich występów solowych obojga artystów, stopniowo stając się modną salonową piosenką. Istotne jest to, że melodia ta opuściła teatr, by rozpocząć niezależną karierę solową.

Koniec lat dziewięćdziesiątych XVIII wieku oraz okres 1800-1835 to czas niebywałej kariery tej canzonnetty ${ }^{53}$. Umieszczano ją w zbiorach arii i pieśni scenicznych: poza przywołanym już zbiorem Le Chansonnier des Graces. Avec la musique gravée des airs nouveaux z 1808 roku, znajdziemy ją również wśród 19 utworów „2 ${ }^{\circ}$ Cahier d'Ariettes et de Romances, avec La Musique” $z$ lat $1808-1811^{54}$, w otoczeniu innych włoskich pieśni (Presso del rio che piange czy Sono innamorato), romansów francuskich (La Queue de lapin), kompozycji Meissoniera ${ }^{55}$ oraz aranżacji G. Morisota ${ }^{56}$.

Ale oprócz tego melodia La mia crudel tiranna okazała się inspiracją dla muzyków proponujących ciaggle nowe jej aranżacje, jak choćby ta na głos z towarzyszeniem harfy i fortepianu, w muzycznym opracowaniu Edwarda Smitha Biggsa, opublikowana w Londynie prawdopodobnie około $1797 \mathrm{roku}^{57}$, albo w późniejszej o rok

regina d'Inghilterra 〈Elżbieta, królowa Anglii〉, w roli Leicestera; 1816 - Otello, ossia Il moro de venecia 〈Otello lub Maur wenecki〉, w roli tytułowej; 1822 - Zelmira, w roli Antenora) i G. Donizettim (1823 - Alfred Wielki, w roli tytułowej); po zakończeniu kariery na scenie poświęcił się pracy pedagogicznej. Zob. S. L a m a c c h i o, Nozzari, Andrea. Hasło w: Dizionario Biografico degli Italiani. T. 78 (2013). Na stronie: http://www.treccani.it/enciclopedia/andrea-nozzari_(Dizionario-Biografico) (data dostępu: 11 IX 2019). Zob. też F. Re gli, Dizionario biografico dei più celebri poeti ed artisti melodrammatici, ecc. 1800-1860. Torino 1860, s. 364. - Ka miń ski: op. cit., t. 1, s. 322; t. 2, s. 289, 296, 314.

Teresa Bertin otti-Radicati (1776-1854) - sopranistka o bardzo błyskotliwej europejskiej karierze (dużo podróżowała, występując w teatrach w Amsterdamie, Lizbonie, Londynie, Monachium, Wiedniu czy Dublinie). Specjalnie dla niej mąż F. A. Radicati skomponował Fedrę (1811) z popisową rolą tytułową. W latach 1811-1812 występowała w londyńskim King’s Theatre, zachwycając publiczność Mozartowskimi rolami w Czarodziejskim flecie i Cosi fan tutte. Po śmierci męża, w r. 1823, Bertinotti porzuciła scenę i poświęciła się pracy pedagogicznej - zob. przypis 31 . Zob. G. Grove, J. A. Fuller Maitland, A. H. S. Wod ehouse, Dictionary of music and musicians (1450-1889) by eminent writers. T. 1. New York 1879, s. 248. - Cyclopedia of Music and Musicians. Ed. J. D. Champlin jr. and W. F. Apthorps. T. 3. New York 1888-1890, s. 173.

53 Zob. przypis 47. Nazwa ta pojawia się w zbiorze pieśni Le Chansonnier des Graces (s. 225).

$54 \ldots 2^{\circ}$ Cahier d'Ariettes et de Romances, avec La Musique. 1808[-1811]”. Paris 1808-1814, nr 3, s. 7.

55 Tytuł pieśni: Si vous avez une femme volage (jw., s. 8). Nie ma pewności co do autorstwa muzyki: czy chodzi o Josepha Meissonniera (1790-1850), gitarzystę, aranżera, kompozytora, czy o jego brata, Jeana Antoine’a (1783-1857), który również komponował i opracowywał utwory teatralne.

56 Utwór o incipicie: Dans cette belle contrée, odnotowano w zbiorze pieśni jako Romance de Lucrèce (jw., s. 15). Autorem słów tej libertyńskiej arii, znanej też pod innymi tytułami: Lucrèce, romance par M. ${ }^{* * *}$ avocat-général du roi, au Parlament de Paris czy Tarquin et Lucrèce, jest XVII-wieczny poeta J.-N.-M. Guérineau de Saint Péravi. Zob. Petite encyclopédie poétique; ou, Choix de poésies dans tous les genres. T. 8. Ed. L. Philip on de La Madela in e. Paris 1804, s. 104-106. Zob. też Nouvelle encyclopédie poétique: ou, Choix de poésies dans tous les genres. T. 14. Paris 1818, s. 6668. - Correspondance littéraire, philosophique et critique de Grimm et de Diderot, depuis 1753 jusqu'en 1790. T. 2. Paris 1829, s. 455-456.

57 Zbiór E. S. Bigg s a (Twelve Venetian Airs. Rt. Birchall [ok. 1797]) zawiera aranżacje popularnych w XVIII w. pieśni włoskich: 1. La biondina in gondoletta; 2. O miei cari Veneziani, 3. S'e pur vero quel dite; 4. Vo stare sulla mia; 5. La mia crudel tiranna (s. 10-11); 6. Non so come la sia; 7. Senti cara Ninetta; 8. Cangia quel tuo rigore; 9. Irene dov'è Irene; 10. Senza costrutto o cara; 11. 
wersji Jana Křtitela Vaňhala (Johanna Baptysty Vanhala vel Wanhalla) Arietta Italiana: la mia crudel tiranna \&.c. con sei Wariazioni per il Pianoforte z 1799 roku ${ }^{58}$. „Wenecjankę" wpleciono także w bukiet 7 popularnych arii, zaaranżowanych na harfę oraz flet lub skrzypce przez kompozytorkę i instrumentalistkę Sophię Dussek, która też sama wykonywała tę pieśn na koncertach ${ }^{59}$. Chwalono dedykowane Aleksandrowi Scottowi wariacje fortepianowe na temat tej pieśni autorstwa Jeana Théodore'a Latoura, pianisty księcia Waliii ${ }^{60}$, słuchano innej wersji na tenże instrument Josepha Jelinka (Gelinka) ${ }^{61}$, do pianistycznego Pot pouri włączył ją Christopher Meineke ${ }^{62}, \mathrm{z}$ uznaniem przyjmowano subtelną ornamentykę wersji na niemiecki flet Charlesa Sausta ${ }^{63}$, wreszcie śpiewano ja $z$ akompaniamentem gitary opracowanym przez Luigiego Picchiantiego ${ }^{64}$. Wydaje się, że ten materiał czeka na wnik-

Misera son tradita, 12. L'amore che sento dentro del petto. Zapis dwu wariantów melodycznych zob. aneks I 6.

58 Zob. J. K. V a ňh al / J. B. V an hal / W a n hall, Arietta Italiana: la mia crudel tiranna \&.c. con sei Wariazioni per il Pianoforte. 1799. Wykazują tę publikację: „Allgemeine musikalische Zeitung”. Hrsg. F. Rochlitz. T. 1. Leipzig 1798 (Musicalien, Instrumentalmusik IX). - J. G. Me u s el, Teutsches Künstlerlexikon oder Verzeichniss der jetztlebenden teutschen Künstler: nebst einem Verzeichniss sehenswürdiger Bibliotheken, Kunst-, Münz- und Naturalienkabinette in Teutschland und in der Schweiz. T. 2. Lemgo 1809, s. 478.

59 The favorite airs, of Drink to me only, La Mia crudel tiranna, \&My ain kind deary O! with variations for the harp, and flute or violin accompt. ad libitum, composed, arranged [...] by S. Dussek. Set 7. London 1815. W katalogu Women Composer Collection Inv. (poz. 935) - nieco inna data publikacji owego druku [1810?]. Zob. Women Composers Author Index - Gale - tu jej kompozycje odnotowane sa pod panieńskim nazwiskiem: Sophia Corri; powtórzono informację o publikacji (z 1810 r.?) za wcześniejszym źródłem (s. 55). Gr e e ne (op. cit., s. 3444) rejestruje koncertowy występ Dussek w dublińskim teatrze 16 III 1805 - śpiewała wówczas La mia crudel tiranna, akompaniując sobie na harfie.

60 „Sul Margine d'un Rio," a favourite Italian Air, arranged as a Duet for the Harp and Piano forte. By T. Latour, Pianiste to His Royal Highnes, the Prince of Wales (wydanie tych wariacji komentował „The Monthly Magazine” (1806, t. 22, s. 170〉). - A favourite Italian Air, with twelve Variations for the Piano Forte, with an Accompaniment for the Flute (ad libitum) composed and dedicated to Alexander. Scote, Esq. by T. Latour, Pianiste to His Royal Highnes, the Prince of Wales (wydanie tej kompozycji reklamował periodyk "Cabinet: Or, Monthly Report of Polite Literature” 〈1807, t. 2, s. 330)). Dzisiaj dostępna jest wersja późniejsza: „Sul margine d'un Rio”: A favorite Italian air with 12 variations for the pianoforte with an accompanimentfor the flute ad lib. dedicated to Colonel Nloomfield. Philadelphia [1823-1824] - zob. aneks I 7.

61 J. J elin ek / G eli n ek, Variazioni all'italiana per il pianoforte, sopra l'arietta La mia crudel tiranna d'amarmi un di guiro. Nr 54. Vienna - na tę publikację wskazuje Catalogo-del-Fondo-Bottini, poz. 609. Zob. też Verzeichniss von Musikalien welche in der Musik und Instrumenten-Handlung bey Falter und Sohn in München In der Residenz-Schwabinger-Straße Nro. 33. München 1822, s. 86. - Hofmeisters Handbuch der Musikliteratur. T. 1-3. 1845, s. 164. - T. C h in i, G. To n in i, La raccolta di manoscritti e stampe musicali „Toggenburg” di Bolzano (secc. XVIII-XIX). EDT srl. 1986, s. 800 (poz. 795). - Handbuch der musikalischen Literatur: oder allgemeines systematisch geordnetes Verzeichnis gedruckter Musikalien, auch musikalischer Schriften und Abbildungen mit Anzeige der Verleger und Preise. T. 2. Hrsg. C. F. Wh is tlin g. Leipzig 1828, s. 426.

62 Ch. C. Meineke, Pot pourri. Baltimore [1807-1809?], s. 5 - zob. aneks I 8.

63 Zob. A Collection of favourite Melodies, with appropriate Embellishments, adapted for the German Flute, by Charles Saust, A’o. I. [1800] (i wydania późniejsze 1813-1814). Edycja komentowana w przeglądzie nowych publikacji muzycznych: „The Gentleman’s Magazine” (t. 83, cz. 1; t. 113, 1813, s. 60).

64 L. Pi c c hi i n ti, Trentasei ariette nazionali con accompagnamento di chitarra. Firenze [ok. 1835] zob. aneks I 9. 
liwą analizę komparatystyczną i komentarz muzykologa; zanim to nastąpi, możemy cieszyć się, że w kakofonicznym wieku XXI ktoś dostrzegł i docenił proste i czyste brzmienie „Wenecjanki”, bo powróciła ona w wersji koncertowej i płytowej65.

\section{„Wenecjanki" kontrafakturowe spotkania z tekstem}

Wariabilność melodyczną „Wenecjanki” można uznać za przejaw inwencji każdego kolejnego muzyka opracowującego własną wersję wykonania dobrze znanego tematu muzycznego. Towarzyszy jej jednocześnie zjawisko kontrafaktury, polegające na łączeniu melodii „Wenecjanki” $\mathrm{z}$ wieloma różnymi tekstami. W przypadku polskich wariantów ten motyw muzyczny najtrwalej zrósł się z arią Starego Dominika i stał się ważnym komponentem manifestacji jego stoickiej postawy, braku skłonności do ulegania pokusom świata, akceptacji skromnego losu occiarza:

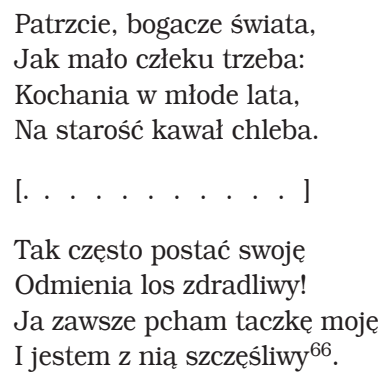

W latach dziewięćdziesiątych XVIII wieku ta teatralna piosnka stała się bezpośrednią inspiracją dla autora parafrazy „Taczka” spiewana przez JW Szczęsnego Potockiego żonie swojej67, persyflażowo rozliczającej polityczne wybory marszałka konfederacji targowickiej:

Popatrzcie, Polacy, patrzcie

Jak mało jest wam potrzeba

Z inicjatywy P. Bassa (flecisty i melomana) w Moulins, w Hôtel du Département, Trio Dauphine (skrzypce - M. Giguet, klawesyn - M. van Rhijn, harfa - C. Izambert) zaprezentowało 22 II 2013 koncert Un Air de bohème dans le salon de Marie-Antoinette. Zaproponowany repertuar muzyczny pozwolił słuchaczom powrócić do estetyki czasów królowej Marii Antoniny. W programie oprócz instrumentalnej wersji La mia crudel tiranna w wariacyjnym przetworzeniu S. Dussek znalazły się również XVIII-wieczne utwory: J.-A. de Mignaux, J. A. Stepana, A. Dumonta oraz L.-Ch. Ragué. Zespół kameralny Trio Dauphine powtórzył ten program, uzupełniając go o sonatę J. L. Dusseka, w koncercie Marie-Antoinette, musicienne et bohème, wykonanym w operze w Lille 1 VI 2016. Zob. na stronach: https://www.opera-lille.fr/fr/saison-15-16/bdd/cat/mercredi/sid/99612_marie-antoinette-musicienne-et-boheme; http://solistes-de-demain.com/wp-content/uploads/2017/06/ programme-concert-du-22-f\%C3\%A9vrier-2013.pdf (daty dostępu: 11 IX 2019).

Wersja płytowa: La mia crudel tiranna w wykonaniu Th. Buscha (baryton) z akompaniamentem gitary M. Agostinellego - utwór na płycie Gabriello Melia: Works For Voice and Guitar z 2004 roku. Zapis przejęty z przygotowywanej przez Kozyrę (op. cit., s. 31, 81-82) edycji Taczki occiarza, opatrzonej komentarzem filologicznym.

67 „Taczka” śpiewana przez JW Szczęsnego Potockiego żonie swojej. W zb.: Wiersze polityczne czasu konfederacji targowickiej i sejmu grodzieńskiego 1793 roku. Oprac. K. M a k s i m ow i c z. Gdańsk 2008, s. 242. 
Do niewoli, którą macie:

Kajdan, wody i chleba.

Lecz byście mieli to troje,

Cierpcie i bądźcie podłymi,

Wywyższę ja wielkość moję,

A was zrobię nikczemnymi ${ }^{68}$.

Z kolei nie satyryczny, lecz patriotyczny charakter zyskała „Wenecjanka”, gdy przeniesiono ją do śpiewanej wersji wiersza Franciszka Karpińskiego Na dzień 3 Maja 1791 szczęśliwie doszłej konstytucji krajowej69. Taki okolicznościowy przykład podała „Gazeta Warszawska” z 7 III 1792 - oto obiad u podkomorzego grodzieńskiego Jundziłła 15 II 1792 został uświetniony odśpiewaniem słów:

Rzucajmy kwiat po drodze!

Tędy przechodzić maja

Szczęścia narodu wodze,

Co nowy rząd składają.

Weźmy weselne szaty!

Dzień to kraju święcony.

Jakże ten król nasz bogaty!...

Skarb jego, serc miliony ${ }^{70}$.

Natomiast już po przystapieniu króla do konfederacji targowickiej melodię „Wenecjanki” towarzysząca wierszowi Karpińskiego spleciono z gorzką strofą utworu Na pieśń „Rzucajmy kwiat po drodze” roku 1791 zrobiona, w czasie konfederacji targowickiej roku 1792 odpisana przez jedna obywatelkę:

\author{
Szczęśliwi, męże zmarli, \\ Żeście nie doczekali, \\ By Wam wolność wydarli \\ I zdradą krew przelali. \\ Grzebcie się głębiej braty, \\ Król tylko nasz jest bogaty, \\ Skarb jego fałsze i zdrady ${ }^{71}$.
}

68 Ibidem. Oba utwory śpiewane do melodii „Wenecjanki”: „Taczka” śpiewana przez JW Szczęsnego Potockiego żonie swojej oraz Na pieśń „Rzucajmy kwiat po drodze” roku 1791 zrobiona, w czasie konfederacji targowickiej roku 1792 odpisana przez jedna obywatelkę (przypis 71) jako pierwsza przedstawiła K. Maks i mowicz w artykule Tarcia polemiczne, „responsy” i trawestacje $w$ szermierce poetyckiej schytku XVIII wieku („Napis” $22\langle 2016\rangle$, s. 58).

69 Przyporządkowywano ów wiersz do melodii „Patrzcie, bogacze świata” zarówno w wydaniach dzieł F. Karpińs kiego (Dzieła. Nakład W. Kras iński. Warszawa 1830, Księga III, XXXII, s. 148), jak i w śpiewnikach (J. H o r o s z k i e w i c z: Echa minionych lat. Wiersze, pieśni z muzyka, marsze wojska polskiego z końca 18. i początku 19. wieku. Lwów 1889, z. 1, s. 11-12; Pieśni z muzyka. Marsze Wojska Polskiego z końca 18. i początku 19. wieku. Zebrał, wyd. ... Z. 1. Kraków 1898, s. 11-12).

70 F. Ka r piń s ki, Na dzień 3 Maja 1791 szczęśliwie doszłej konstytucji krajowej. W: Dzieła, s. 148. Zwrócił na to uwagę Z. Li b e r a w artykule Konstytucja 3 Maja w oczach współczesnychjej poetów („Niepodległość i Pamięć” 2000, nr 1, s. 52).

71 Na pieśń „Rzucajmy kwiat po drodze” roku 1791 [...]. W zb.: Wiersze polityczne czasu konfederacji targowickiej i sejmu grodzieńskiego 1793 roku, s. 133. 
Jak widać, w polskich pozateatralnych realizacjach „Wenecjanki” jej popularność pozwalała uwypuklić polemikę polityczną lat dziewięćdziesiątych XVIII wieku, towarzysząca rozpadowi Rzeczypospolitej.

Nieco inny charakter miało kontrafakturowe wykorzystanie tej melodii w obrębie kultur brytyjskiej i amerykańskiej. Melodię La mia crudel tiranna przywiózł do Londynu skrzypek i kompozytor angielski William Shield i to jemu przypisuje się upowszechnienie „Wenecjanki” z tekstem ballady The Maid of Lodi, ponoć przełożonej z języka włoskiego ${ }^{72}$. Podczas gdy aria La mia crudel tiranna wyrażała paradoks miłości, polegający na współobecności gorącego uczucia i udręki niepewności, podejrzliwości, zazdrości, to The Maid of Lodi, w 5-zwrotkowej wersji Shielda, była niejako fabularnym rozwinięciem włoskiego pierwowzoru à rebours:

\author{
I sing the Maid of Lodi \\ who sweetly sung to me \\ whose brows were never cloudy \\ nor e'er distent with glee \\ she values not the wealthy \\ Unlefs they're great \& good \\ For she is strong and healthy \\ and by labour earns her food \\ And when her days work's over, \\ Around a chearful fire \\ She sings or rests contented \\ What more can man desire? \\ Let those who squander millions \\ Review her happy lot, \\ They'll find their proud pavillions \\ Far inferior to her Cot. \\ Between the Po and Parma, \\ Some Villians seiz'd my Coach; \\ And dragg'd me to a Cavern \\ Most dreadful to approach \\ By which the Maid of Lodi \\ Came trotting from the fair \\ She paus'd to hear my wailings \\ And see me tear my hair. \\ Then to her market basket \\ She tied her poney's rein - \\ I thus by female courage, \\ Was dragg'd to life again, \\ She led me to her dwelling \\ She chear'd my heart with wine, \\ And then she deck'd a table, \\ At which the Gods might dine. \\ Among the mild Madona's \\ Her features you may find
}


But not the fam'd Correggios

Could ever paint her mind

When sing the Maid of Lodi,

who sweetly sang to me:

And when this Maid is married,

Still happier may she be $e^{73}$.

Jest to śpiewany portret dziewczyny pochodzącej z lombardzkiej miejscowości nad rzeką Arno, dziewczyny, której dobroć i spokój, wynikające $z$ cichego szczęścia czerpanego przez nią ze skromnego, pracowitego życia, podbiły serce opiewającego jej zalety młodzieńca-narratora. Przy tym - w zależności od wersji tekstowej, do której sięgniemy - opowiadacz raz jest napadniętym przez złoczyńców podróżnym, a innym razem okrętowym rozbitkiem ${ }^{74}$, którego nieodmiennie dziewczyna $z$ Lodi ratuje $z$ opresji. Nie wiemy, o której wersji wykonanie upominał się lord George Byron w młodzieńczym liście z 29 VIII 1804 do miss Elisabeth Pigot ${ }^{75}$. Nie wiemy również, który wariant pieśni The Maid of Lodi wykonano w roku 1815 podczas biesiadnych toastów $\mathrm{w}$ trakcie jednego $\mathrm{z}$ towarzyskich obiadów w domu Jamesa Ballantyne'a, gdy gospodarz podejmował słynnego pisarza Waltera Scotta ${ }^{76}$. Mamy natomiast pewność, że obieg społeczny tej ballady był powszechny, o czym świadczy przedrukowywanie jej słów w piosennikach angielskich, szkockich, irlandzkich i amerykańskich pierwszej połowy XIX wieku, najczęściej bez wskazania, do jakiej melodii miały być wykonywane ${ }^{77}$. Oczywiście, melodyczną i aranżacyjną wersję

73 Tekst pochodzi $z$ wydania nutowego The Maid of Lodi: A Favorite Ballad with an Accompaniment for the Harp Or Piano Forte ze zbiorów W. Shielda (Clementi, Banger, Hyde, Collard\&Davis, 26 Cheapside 1805) - wersja powtórzona w wydaniach z 1807 r. (oryginał w: The British Library) - zob. aneks II 2.

74 Maid of Lodi. A favorite ballad with an accompaniment for the harp or piano forte. The music collected by Mr Shield, when in Italy. London 1804 (obok wersji na głos z towarzyszeniem harfy lub fortepianu, zawiera odrębny zapis nutowy na flet lub gitarę; oryginał w: The British Library).

Letters and Journals of Lord Byron: With Notices of His Life. T. 1. Ed. Th. M o o r e. New York 1830, s 62-63 (lub: Francfort 1831, s. 31). Elisabeth Pigot była przyjaciółką młodości i adresatką listów nastoletniego Byrona $\mathrm{z}$ czasów, gdy rodziny obojga korespondentów mieszkały w Southwell - zob. I. Pr e g n o la t o, Elizabeth Bridget Pigot: Byron's Female Friend. Na stronie: http://byron.nottingham.ac.uk/archive (data dostępu: 25 IX 2019).

Zob. J. G. L o ck ha rt, Memoirs of the Life of Sir Walter Scott. T. 2. Paris 1837, s. 291. Zob. też Critical and Miscellaneous Essays Collected and Republished by Thomas Carlyle. T. 4. London 1847, s. 140.

77 Zob. A Garland of New Songs, Containing. 1. The Maid of Lodi. 2. A Peep at the Forty Thieves. 3. Nobody Comes to Marry Me. 4 Seven Ages. B. m., 1790. - A Garland of New Songs: The Post Captain, the Maid of Lodi, the Beggar Girl, Sally in Our Alley, the Woodland Maid. B. m., 1800, s. 3-5. The Northern Minstrel: Or, Gateshead Songster. Being a Choice Collection of the Most Approved Modern Songs: Including Also, a Number of Originals, from the Manuscripts of the Respective Authors. B. m., 1806, s. 46-47. - A Favourite Masonic Song. Called Fill Up a Bumper. To which are Added, She Lives in the Valley, Tell Her I Love Her, The Maid of Lodi, Nan of Hampton Green. Belfast, b. r., s. 3-4. - A New Song Called An Irishman's Heart for the Ladies. To which are Added, The Maid of Lodi, Willie Brew'd a Peck O' Maut, The Song of the Last Harper, Tom Bowling, and Paddy the Piper. Ed. Ch. Dibdin. Belfast [1810?], s. 3-4. - A New Song Called The Bold Dragoon to which are Added, Young William, The Maid of Lodi, One Bottle More, The Lass of Patie's Mill, and My Bonny Nanny O., Hawkers. B. m., [1810?], s. 4-5. - The woodman; The pocket encyclopedia of Scottish, English, and Irish songs, selected from the works of the most eminent poets; with original pieces, and notes. B. m., 1816, s. 119. - The Vocal Library: Being the Largest Collection of English, Scottish, 
Shielda równie często drukowano repetycyjnie we wznowieniach lub wariacyjnie przetwarzano $^{78}$.

Rodzi się pytanie, czy ballada ta, podobnie jak jej poprzedniczka, La mia crudel tiranna, była pieśnią wszczepianą do spektakli operowych - zapis w niektórych wyciagach muzycznych by na to wskazywał ${ }^{79}$. Może być jednak i tak, że to poczucie teatralności wiązało się ze świadomością zapożyczenia włoskiej melodii teatralnej przez angielską balladę. Na karcie tytułowej amerykańskiego wyciagu muzycznego „Wenecjanki”, opublikowanego na początku XIX wieku z nowym angielskim tekstem, widniał zapis: The Maid of Lodi or La mia crudel tiranna, Venetian air ${ }^{80}$, w późniejszych wersjach najczęściej nie wskazywano już jednak tej włoskiej genealogii melodycznej. Ślad świadomości proweniencji teatralnej The Maid of Lodi odnajdziemy we wspomnieniu XIX-wiecznego londyńskiego aktora Edwarda Cape’a Everarda, który kąśliwie skwitował umiejętności kolegi przygotowującego się do wokalnego występu, podkreślając, że nie można spodziewać się po nim niczego wyrafinowanego, ponieważ śpiewak ten nie odróżnia La mia crudel tiranna od Hey, down-derry down ${ }^{81}$. Innym przykładem może być sposób skomentowania w kronice teatralnej „The Athenaeum” z roku 1828 motywu muzycznego wykorzystanego przez Rossiniego w operze Otello - autor prasowej notatki dopatrzył się podo-

and Irish Songs, Ever Printed in a Single Volume. Selected from the Best Authors Between the Age of Shakspeare, Jonson, and Cowley, and that of Dibdin, Wolcot, and Moore. London 1824, s. 448. Minstrel : a collection of popular songs. Philadelphia 1826, s. 264-265. - The New England Pocket Songster: A Choice Collection of Popular Songs. Claremont 1846, s. 12-13. Zob. też aneks II 3.

78 Zob. Five songs. Miss Drummond. Jockey's far awa'. The blue ey'd lassie. The maid of Lodi. Maggy Laudes. B. m., [1800?]. - The maid of Lodi: a favorite ballad: with an accompaniment for the harp or piano forte / the music by a lady of fashion. London [1802?]. - Edinburgh repository of music Containing the most select English, Scottish \& Irish airs. 2 volumes in 1. Edinburgh [1818, 1825], s. 50 (melodyczna prymka). - [Collection of sheet music from the late 18th century]. B. m., 1790, s. 69-70 (wersja Shielda, z akompaniamentem harfy i fortepianu). - B. C a r r, The Maid of Lodi. B. m., [1812?] (wersja na fortepian). Na stronie: https://www.loc.gov/resource/musmlal.10710. $0 / ? \mathrm{sp}=2 \& \mathrm{r}=-0.866,0.026,2.732,1.273,0$ (data dostępu: 25 IX 2019; zob. też aneks I 10). W. F. S mith, Introduction and variations on the admired air „The Maid of Lodi” for the Flute, etc. Op. 4. London 1820 (na flet $\mathrm{z}$ towarzyszeniem fortepianu). - J. Parry, Two thousand Melodies, selected from the works of eminent English and Foreign authors [...] Arranged for the Flute, Violin, Oboe, or Clarionet, most of which may be played on the Cornet à piston, Keyed Bugle, or Accordion [...]. London 1841, s. 38 (zapis tematu muzycznego). - W. M. Cahusac's Annual Collection of Twelve favorite Country Dances, with their Basses, For the Year 1804, with proper Directions to each Dance, as they are Performed at Court, Bath, and all Public Assemblys. London 1804 (tu: taneczna wersja The Maid of Lodi). - Select collection of all the marches, minuets, waltzes \& airs performed by the Pandean's band at Vauxhall. London, b. r., s. 28 (wersja na fortepian).

79 Zob. zapis katalogowy kompozycji Shielda: „The Maid of Lodi”. L. fol. B. r. Mus. Marian, an opéra. (Kl.-A.) L. 1788. - Biographisch-bibliographisches Quellen-Lexikon der Musiker und Musikgelehrten der christlichen Zeitrechnung bis zur Mitte des neunzehnten Jahrhundert. T. 5. Leipzig 1903, s. 158.

80 Zob. aneks I 11. Por. z nota komentatora muzycznego, który opisując nową publikację nutowa z r. 1828: Six Italian National Airs, with an Accompaniment for the Spanish Guitar Gulianiego, podkreśla, że aria La mia crudel tiranna użyczyła Shieldowi melodii do nowej pieśni The Maid of Lodi-zob. „The Athenaeum” 1828, nr 34, s. 540.

81 Memoirs of an unfortunate son of Thespis; being a sketch of the life of Edward Cape Everard, comedian. Edinburgh 1818, s. 112-114. 
bieństwa linii melodycznej fragmentu „A me dicesse il ver” do The Maid in Lodi, przy czym zaznaczył, że nie tyle chodzi o wykazanie plagiatu, ile o podkreślenie klasycystycznej prostoty, bardziej odpowiadajacej stylowi muzycznemu Mozarta niż Rossiniego ${ }^{82}$.

Wśród różnorakich wątpliwości i niedookreśleń pojawia się jeszcze jeden palimpsestowy wątek - wyobraźnię rozbudza dostrzegalne podobieństwo motywu tematycznego śpiewki Starego Dominika z przewodnim watkiem The Maid of Lodi: $\mathrm{w}$ obu przypadkach bohaterowie czerpią radość $z$ codziennego zatrudnienia, nie pragna bogactw, czy fortunniejszego losu, kontentujac się życiem takim, jakie jest. Wystarczy powiązać tę zbieżność tematyczną z faktem, że The Maid of Lodi włączono do irlandzkiego śpiewnika masońskiego ${ }^{83}$, a mason Bogusławski ${ }^{84}$, wszczepił „Wenecjankę” we własnej wersji tekstowej do przetłumaczonego przez siebie utworu scenicznego Merciera - wolnomularza należącego do słynnej loży des Neufs Sœurs ${ }^{85}$. W tym świetle wygłoszona przed zaśpiewaniem piosnki „Patrzcie, bogacze świata” kwestia Starego Dominika, pouczającego swego syna, na czym polega szacunek do samego siebie, nabiera dodatkowego znaczenia: „Wstydzić się mojej taczki? - Kiedy tak, poczekajże. Otóż na złość tobie, po tej polerowanej śpiewał moję zwyczajna piosneczkę póty, póki pan Delomer nie usłyszy i nie przyjdzie tu do mnie" 86 . Słowa te bowiem można odczytać jako świadomą prowokację mieszczanina, któremu poczucie godności nie pozwala dostosowywać się do reguł stanowionych dotąd przez arystokrację. Ta zwyczajna piosnka skrzętnego, zapobiegliwego occiarza i musztardnika ma być sposobem wyznaczenia strefy równoprawnego kontaktu dwu do tej pory zróżnicowanych statusem społecznym stanów.

Przypomnę, że na przełomie wieku XVIII i XIX arię „Patrzcie, bogacze świata” publikowano w śpiewnikach jako utwór otwierajacy zbiór, co świadczy o jej randze i popularności w tamtym okresie. Chciałabym potwierdzić, że i w polskich śpiewnikach wolnomularskich ${ }^{87}$ tego czasu możemy ją znaleźć, ale niestety tak nie jest. I choć przesłanki jej wolnomularskiego znaczenia są nader wątłe, to miło jest pomyśleć, że za sprawą „Wenecjanki” być może dotknęłam jednego z masońskich sekretów...

„The Athenaeum” 1828, nr 41, s. 652.

Zob. aneks II 4.

Według L. Ha s s a (Sekta farmazonii warszawskiej. Pierwsze stulecie wolnomularstwa w Warszawie 〈1721-1821〉. Warszawa 1980, s. 225, 246, 280-283) Bogusławski od 1785 r. należał najpierw do loży krakowskiej przy Wielkim Wschodzie, potem do warszawskiej Świątyni Izis i Świątyni Mądrości. Tę pierwszą informację kwestionuje Raszewski (Bogusławski, t. 1, s. 155; zob. też ibidem, s. 350, przypis 9), uznając, że to błędne wskazanie zostało zweryfikowane w publikacji S. Mała ch ow ski e go - Łe m p i cki e go Wojciech Bogusławski wolnomularzem („Ruch Literacki” 1929, nr 3).

Zob. R. A m a d o u, Un Discours maçonnique de Louis Sébastien Mercier. Soyons maçons et point académiciens. „Renaissance traditionnelle” 1973, nr 13. Zob. też L. A mi a ble, Une Loge maçonnique d'avant 1789: la loge des Neuf Sœurs. Paris 1897.

Kozyra, op. cit., s. 81.

Zob. Pieśni wolnomularskie. Warszawa [ok. 1810]. - Pieśni wolnomularskie z różnych autorów zebrane, Loży Symbolicznej Wschodzacego Stońca na Wschodzie Łomży. Łomża 1816. - Pieśnik wolnomularski. Wrocław 1818. 


\section{A NEKS I}

\section{WERSJE MUZYCZNE „WENECJANKI”}

1. Piosnka Starego Dominika ze sztuki Taczka occiarza w XIX-wiecznym zapisie O. Kolberga. Źródło: Z. Ra s ze w s ki, Na nute „Wenecjanki”. (1986). W: Trudny rebus. Studia i szkice z historii teatru. Wrocław 1990, s. 148.

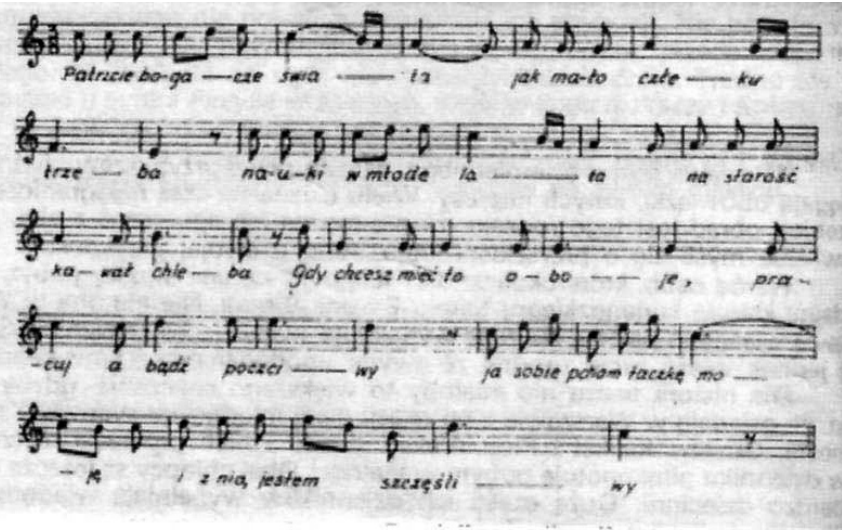

2. Piosnka Starego Dominika z Taczki occiarza - wersja instrumentalna w opracowaniu na klawesyn $z$ premiery spektaklu. Źródło: jw.

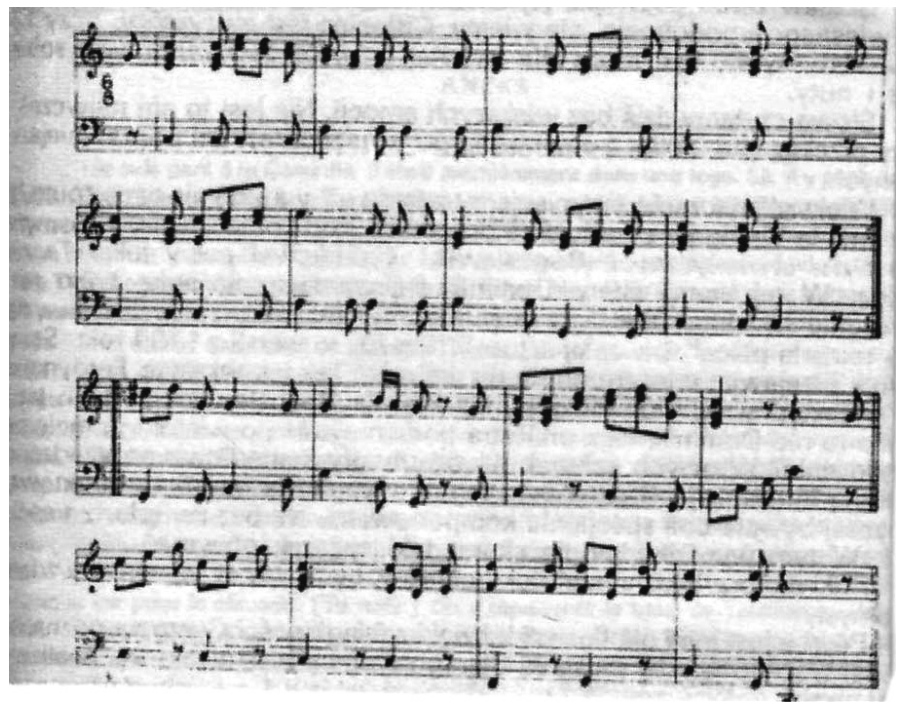


3. Aria della "Cosa rara”, cantata dal signor Nozari, avec accompagnement de piano et des paroles françaises. [Kompozytor: V. Martín y Soler]. Paris [1800]. Źródło: Gallica, BnF.

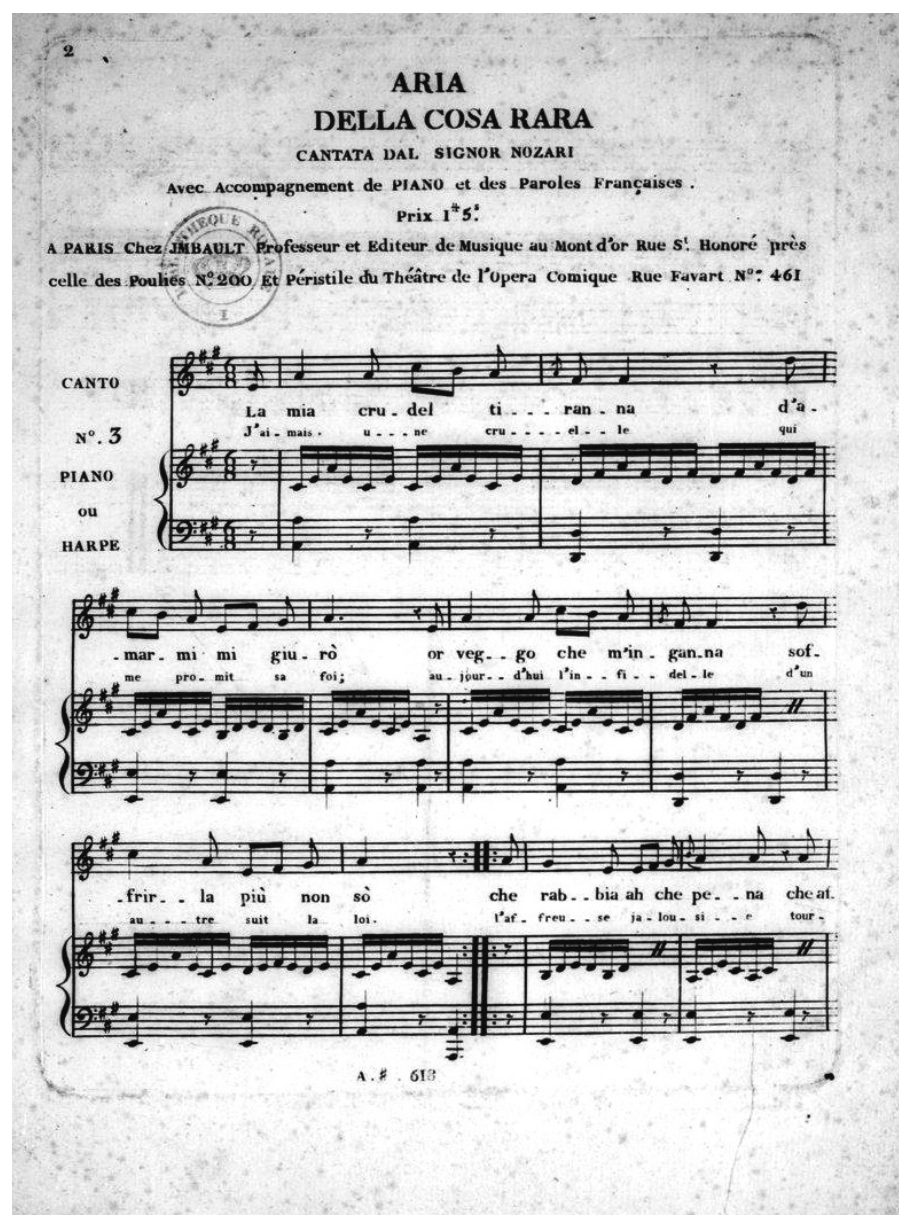


4. Karta tytułowa i pierwsza strona arii veneziana zatytułowanej La mia crudel tiranna ze spektaklu Due nozze e un sol marito (druk z r. 1815). Źródło: Google Books.

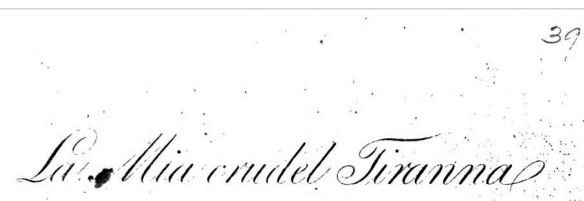

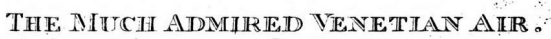

as sung in the Operii of

LE DUE NOZZE E UN SOL MARITO, (ख)

Q Madame OBertinolli Padicatio. WWITH VATRIATITDNSS

(6) Gompose Giy

seluie teradiati?

Ent at Stat" Hall

LIONDON.

Price 2

Finted by Goulding \& Co 20 Soho Square \& y Wertmoreland S:Dublin.
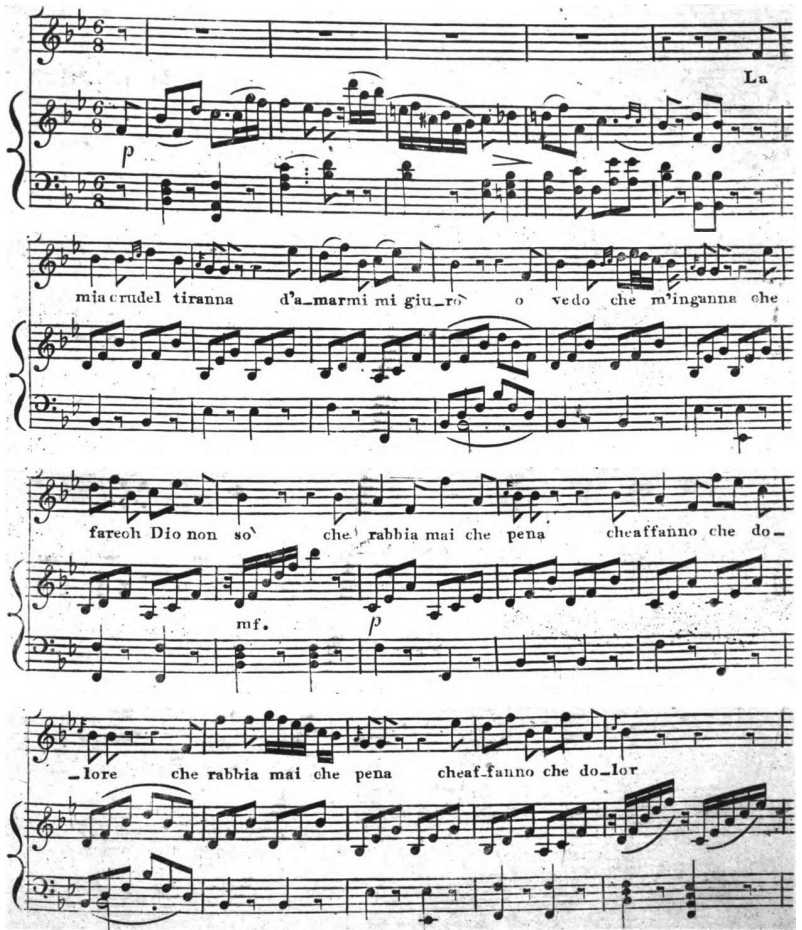
5. Śpiewnik Le Chansonnier des Graces. Avec la musique gravée des airs nouveaux. Paris 1808; dodatek nutowy - s. 25 (nr 35). Źródło: Google Books.

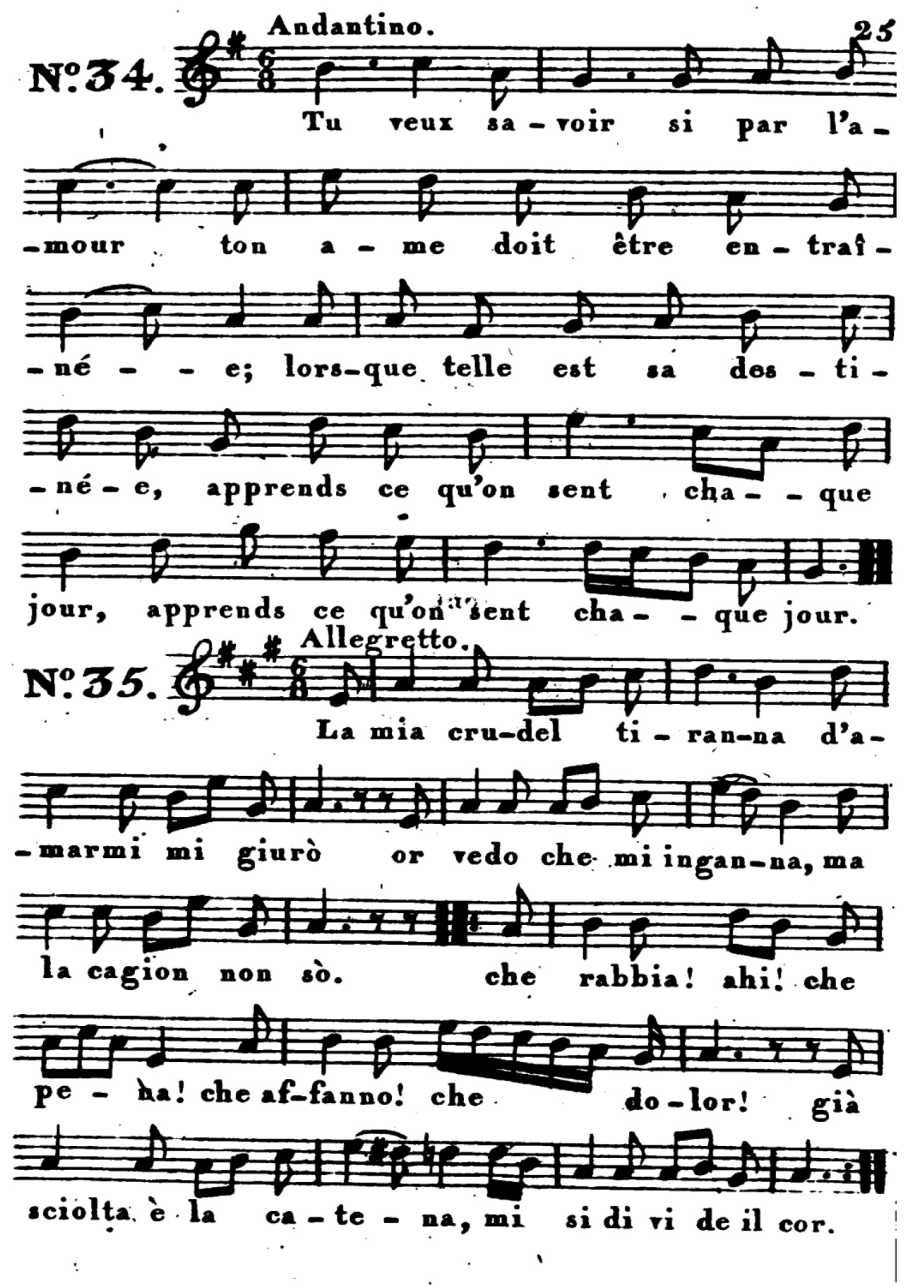


6. E. S. Bigg s, Twelve Venetian Airs. Rt. Birchall [ok. 1797]. Źródło: https://archive.org/stream/ twelvevenetianai0lbigg\#mode/2up.
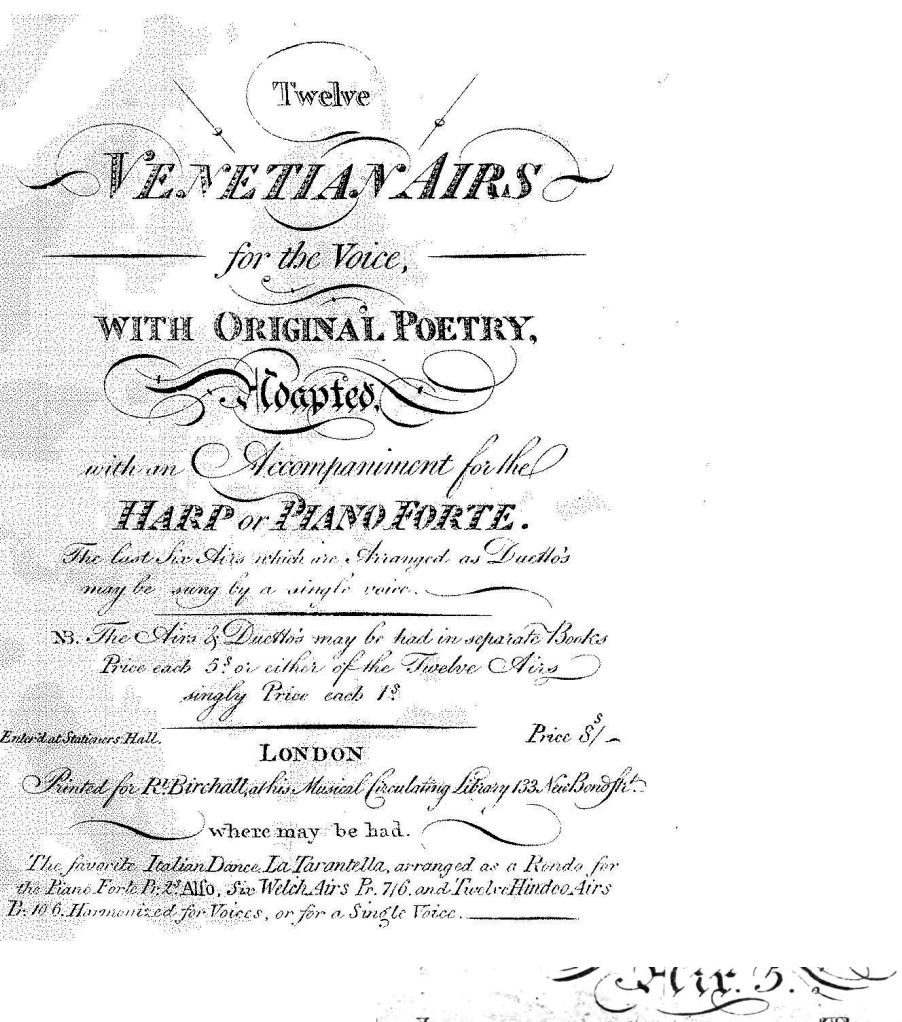

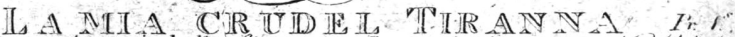
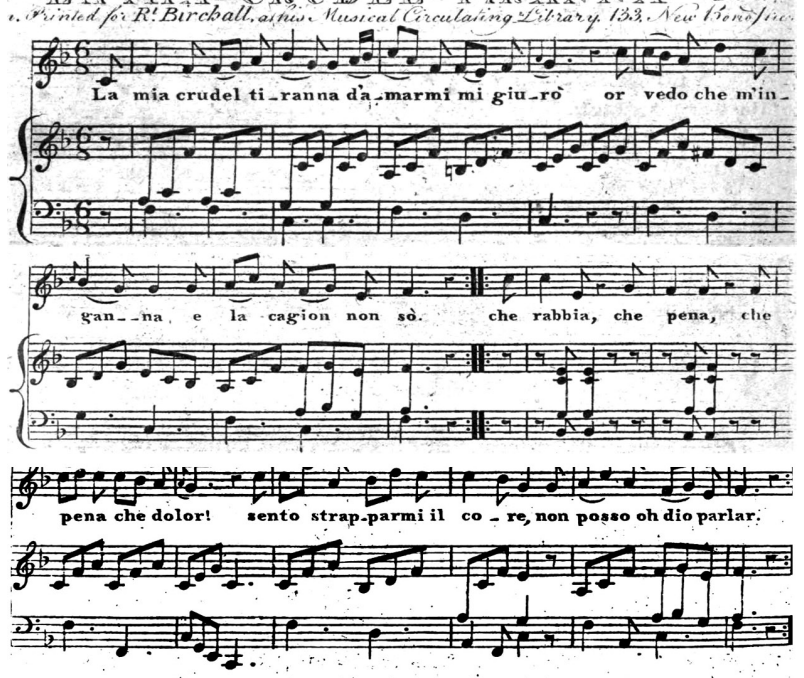

2

Vido. a cercarne un altra, Chabbia di me pietà;

Che non sia tanto scaltra, Chabbia piu fedeltà:

Che rabbia dic.
3

or sincero.

E'gran difficoltä;

Fra voi se dico il vero,

Qualch una lo saprá.

Cho ralbiat \&e. 
7. Wersja J. Th. La t o u r a, pianisty ksieccia Walii: „Sul margine dun rio”: A favorite Italian air with 12 variations for the pianoforte with an accompanimentfor the flute ad lib. dedicated to Colonel Nloomfield. Philadelphia [1823-1824]. Źródło: https://www.loc.gov/resource/musmla1.11571.0/?sp=1\&r=-0.866, -0.368,2.732, 1.273,0.
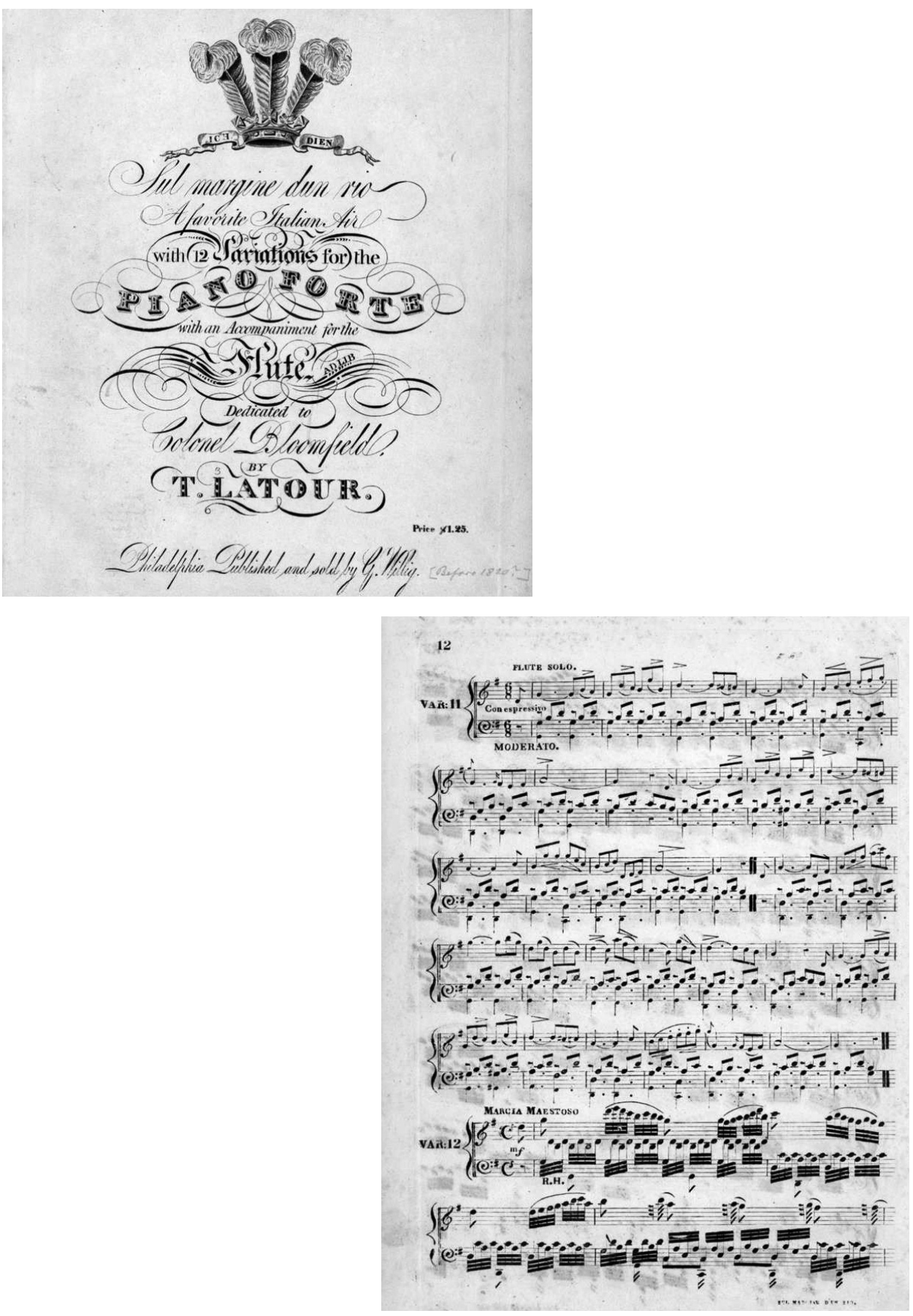
8. Ch. C. Me in eke, Pot pourri. Baltimore [1807-1809?]. Źródło: https://babel.hathitrust.org/ cgi/pt?id=mdp. $39015096473734 \& v i e w=1$ up\&seq=1.

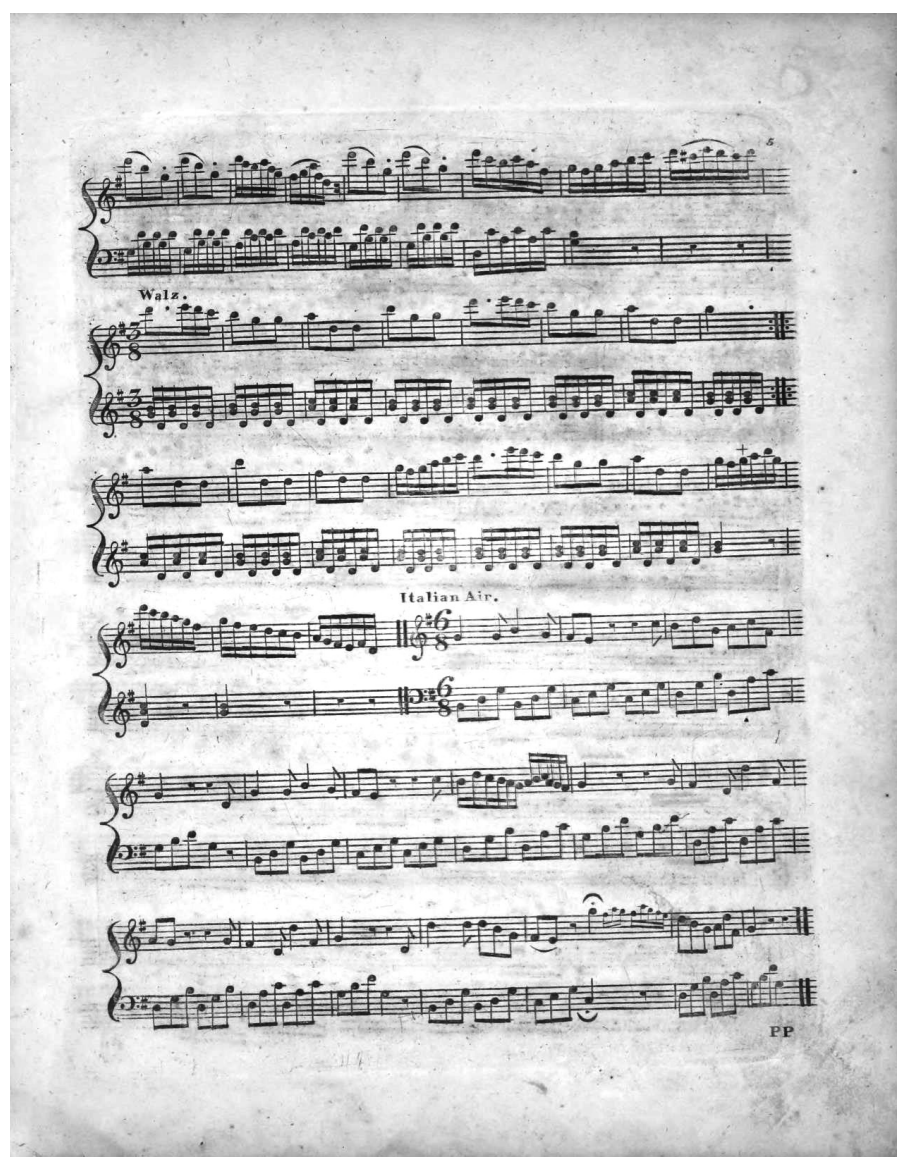


9. L. Pi c c hi a n ti, Trentasei ariette nazionali con accompagnamento di chitarra. Firenze [ok. 1835]. Źródło: https://reader.digitale-sammlungen.de/de/fs 1/object/display/bsb11161478_00005.html.

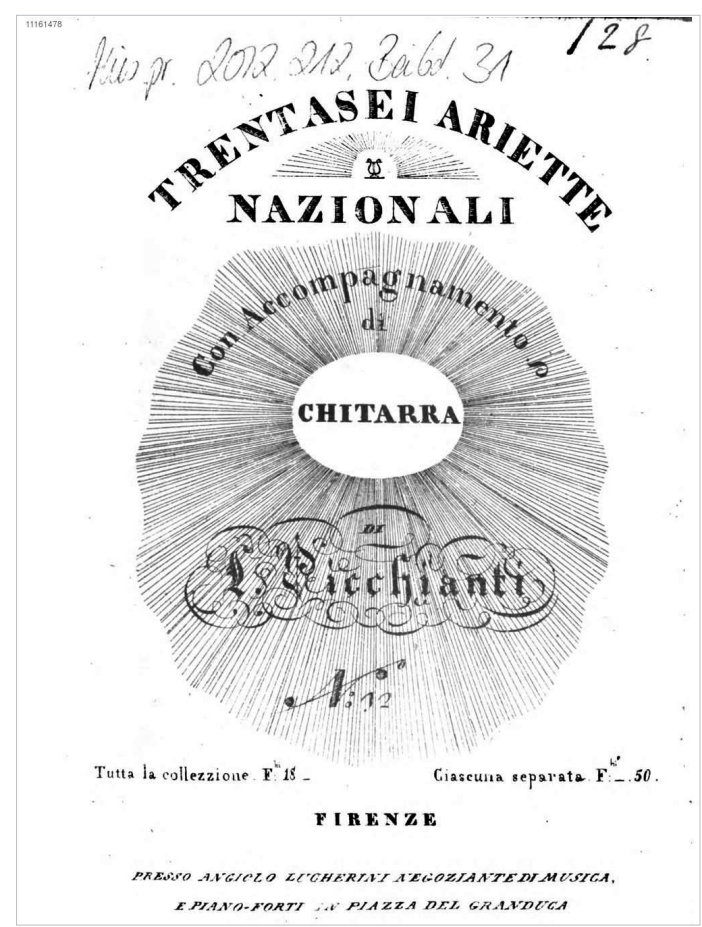

\section{MIA CAUURETIRANAS}

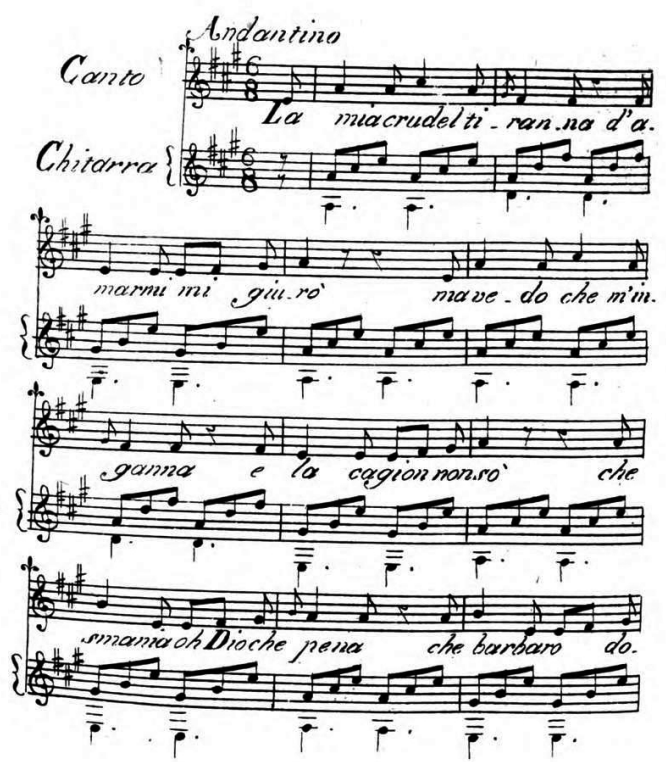


10. Amerykańska wersja B. Carra, przedrukowana w: Anthology of Early American Keyboard Music, 1787-1830. Źródło: https://www.areditions.com/arfiles/product_images/A001Y014_samples. pdf.

[14] The Maid of Lodi

with Variations

(published ca. 1809)
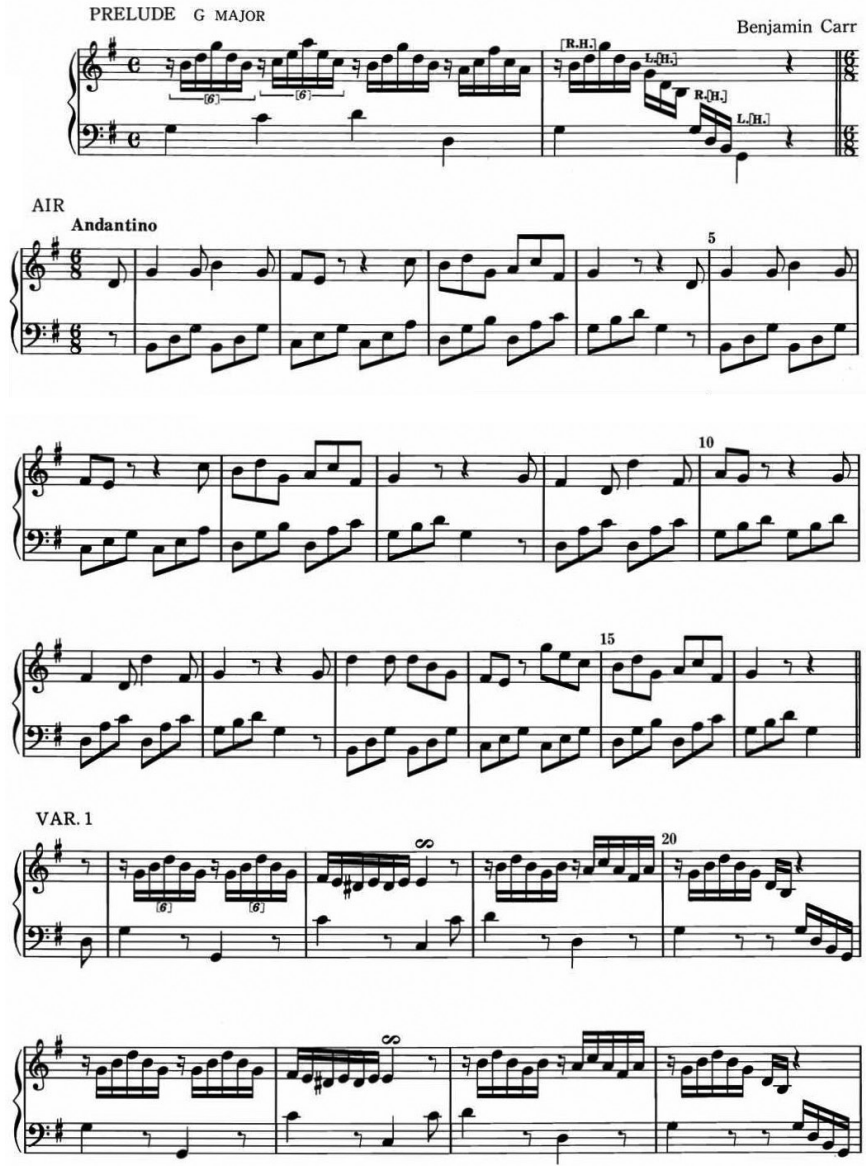
11. G. E. Willi a m s, (G. E b e n e z e r), The Maid of Lodi, or La Mia crudel tiranna a Venetian air arranged as a rondo for the piano forte and inscribed to Miss Austin, G. E. Blake No. 1. Philadelphia [1807-1808]. Library of Congress Control Number: 2015562631.

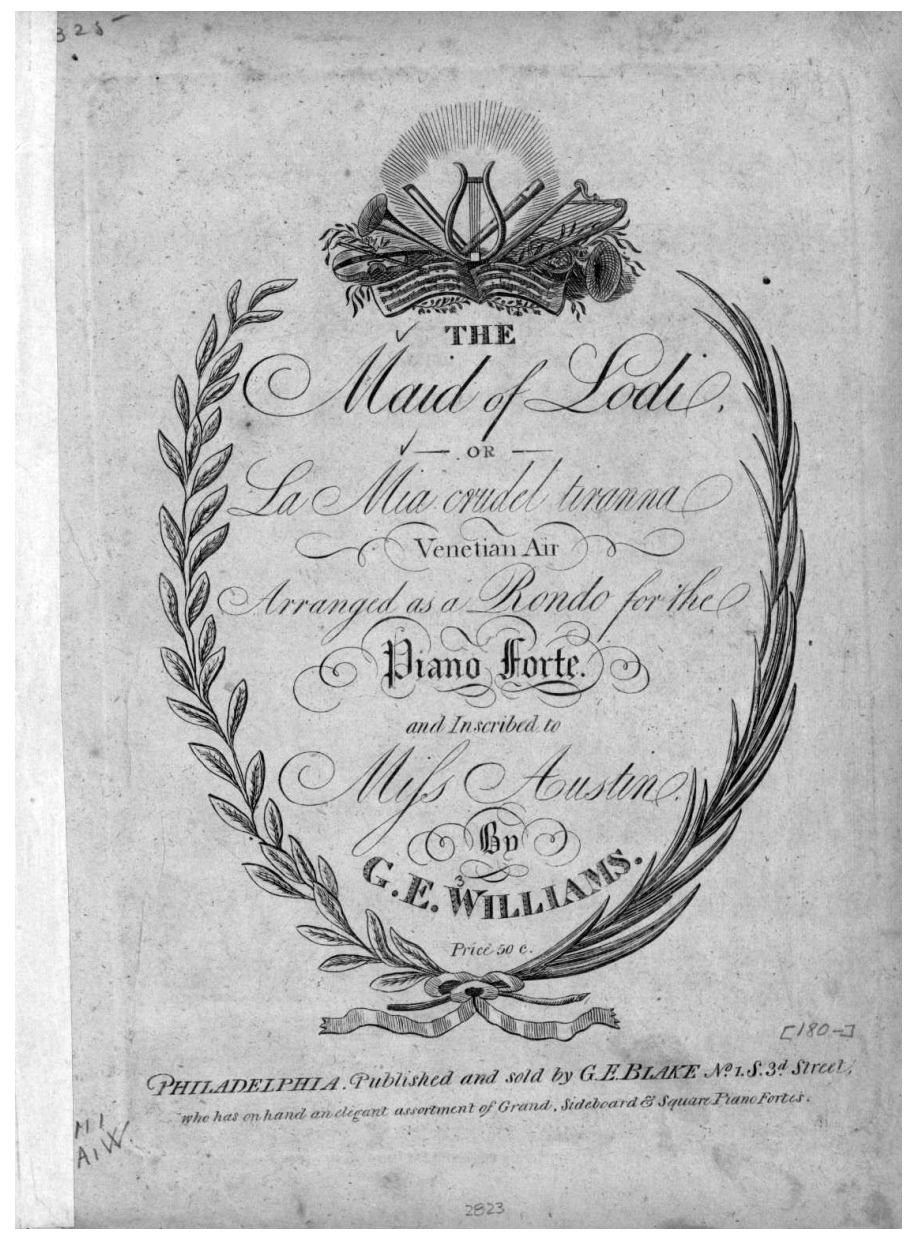




\section{ANEKS II}

WERSJE TEKSTÓW "LA MIA CRUDEL TIRANNA" I „THE MAID OF LODI"

1. Śpiewnik Le Chansonnier des Graces. Avec la musique gravée des airs nouveaux. Paris 1808 , s. 225 - słowa; dodatek nutowy - s. 25 (nr 35). Źródło: Google Books.

ḊES GRACES.

225

\section{CA NZONETTA.}

Musica del Signor Bianchị.

Aria notata $n^{\circ} 35$.

$L_{\text {A mia crudel tiranna }}$

D'amarmi mi giurọ̀;

Or vedo che mi inganna,

Ma la cagion non so.

Che rabbia! ahi! che pena!

Che affanno, che dolor!

Gia sciolta è la catena,

Mi si divide il cor.

Credei a quei bei sguardi

Sincero parve amor,

E. furon tanti dardi

Che mi feri nel cor.

Dal duolo, e dal affanno

Non fò che sospirar :

Se penso a un cor tiranno,

Non fò che lagrimar.

i Lontano porto il passo;

Sol pace cercar vò.

Pietade avrebbe un sasso;

Piu pace no non hò,
326

\section{LE CHANSONNIER}

Mi chiamerai mio biene,

Deh? vieni! per pieta!

Son sciolte le catene,

E tardi allor sard.

L'A UTOM N E.

\section{ROMANCE.}

Musique de M. Villoteau.

Air noté n' 27.

Mrs amis, le soleil a moins dé vïolence, Ses feux sont tempérés par la fraicheur des nuitsLa Vierge dans le ciel fait place à la Balance, Et je vois dans les champs l'automne qui s'avance Arec sa couronne de fruits.

Salut, heureux coteaüx que la vigne décore! Et vous, riants vallons, vergers délicieux, Où d'un teint différent chaque fruit se colore, L'aspect de mes amis vous enrichit encore Et vots rend plus beaux à mes yeux.

Que ne puis-je avec vous dans un repos ntile Habiter loin du bruit ce séjour écarté ! O mes amis, fuyons le fracas de la ville, Et faisons à jamais de ce champêtre asile Celui de la félicité !

M. L. F， JAU prener. 
2. Bostońska wersja wyciągu muzycznego $\mathrm{z}$ tekstem The Maid of Lodi, na głos, harfę i fortepian, powtarzającego zapis Shielda (Boston [ok. 1807]). Źródło: https://imslp.org/wiki/The_Maid_of_Lodi_ (Shield\%2C_William).

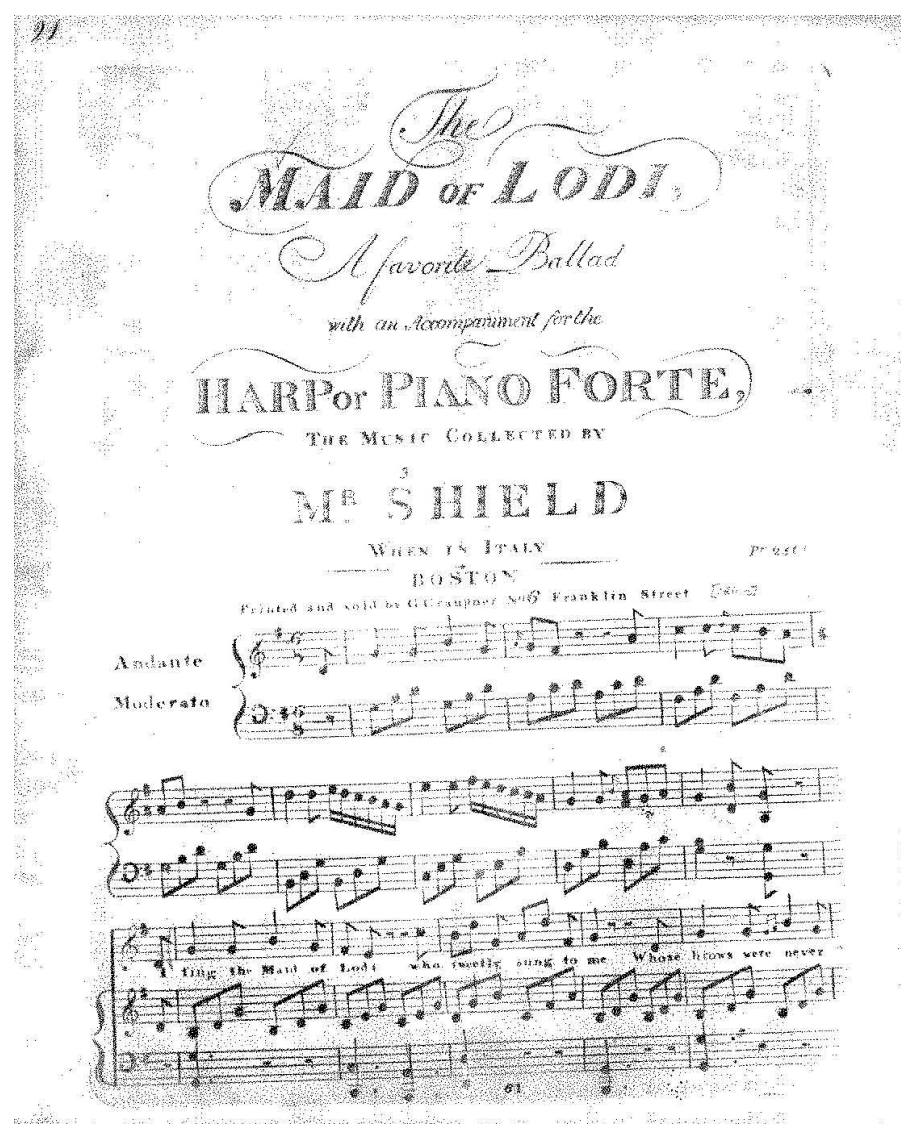


3. Broadside Ballads Online - a digital collection of English printed ballad-sheets from between the 16th and 20th centuries - ballada The Maid of Lodi, Roud Number: V5451. Źródło: http://ballads.bodleian.ox.ac.uk/view/sheet/18364.

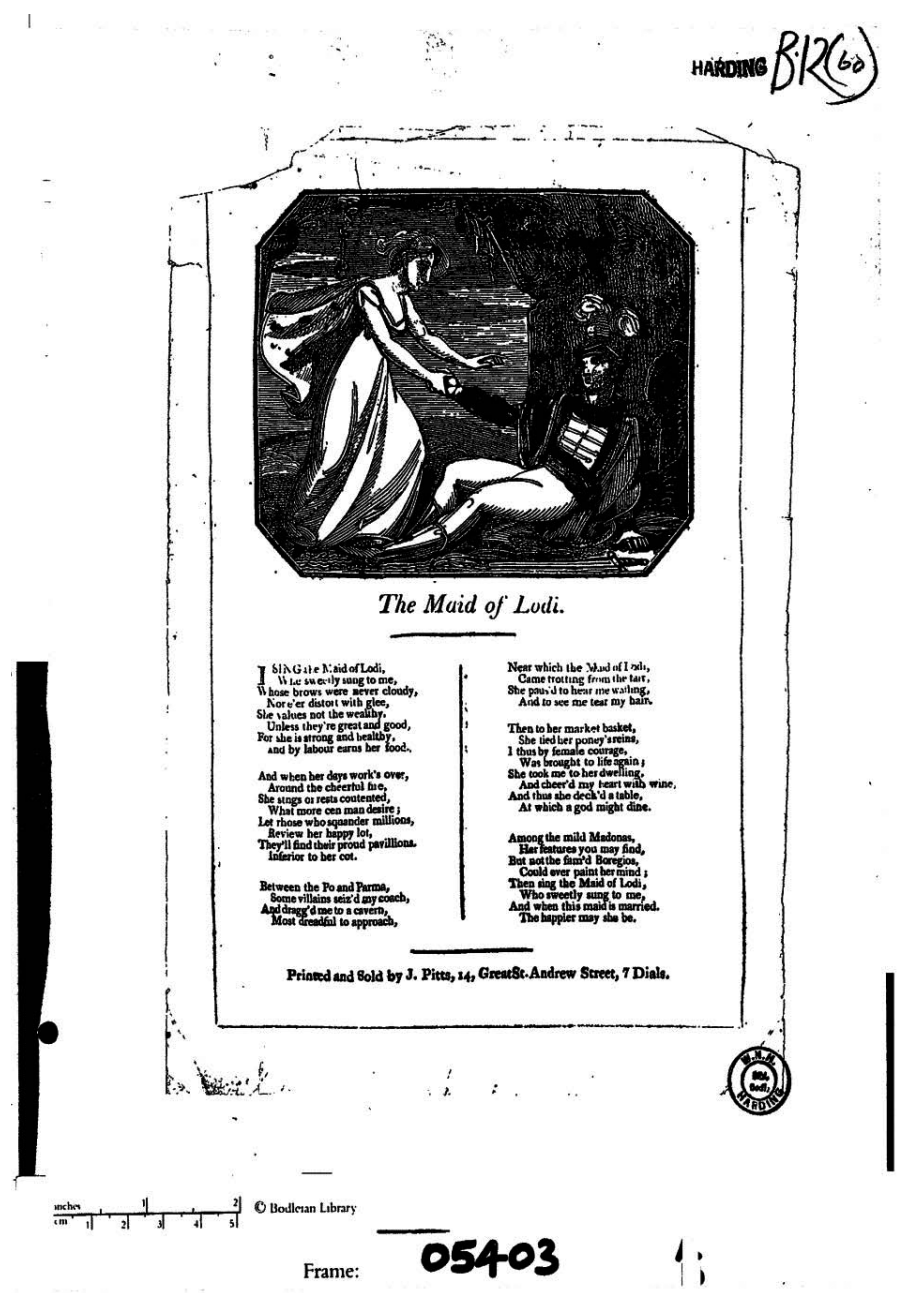


4. Karta tytułowa irlandzkiego śpiewnika masońskiego: A Favourite Masonic Song. Called Fill Up a Bumper. To which are Added, She Lives in the Valley, Tell Her I Love Her, The Maid of Lodi, Nan of Hampton Green. Belfast, b. r. Źródło: Google Books.

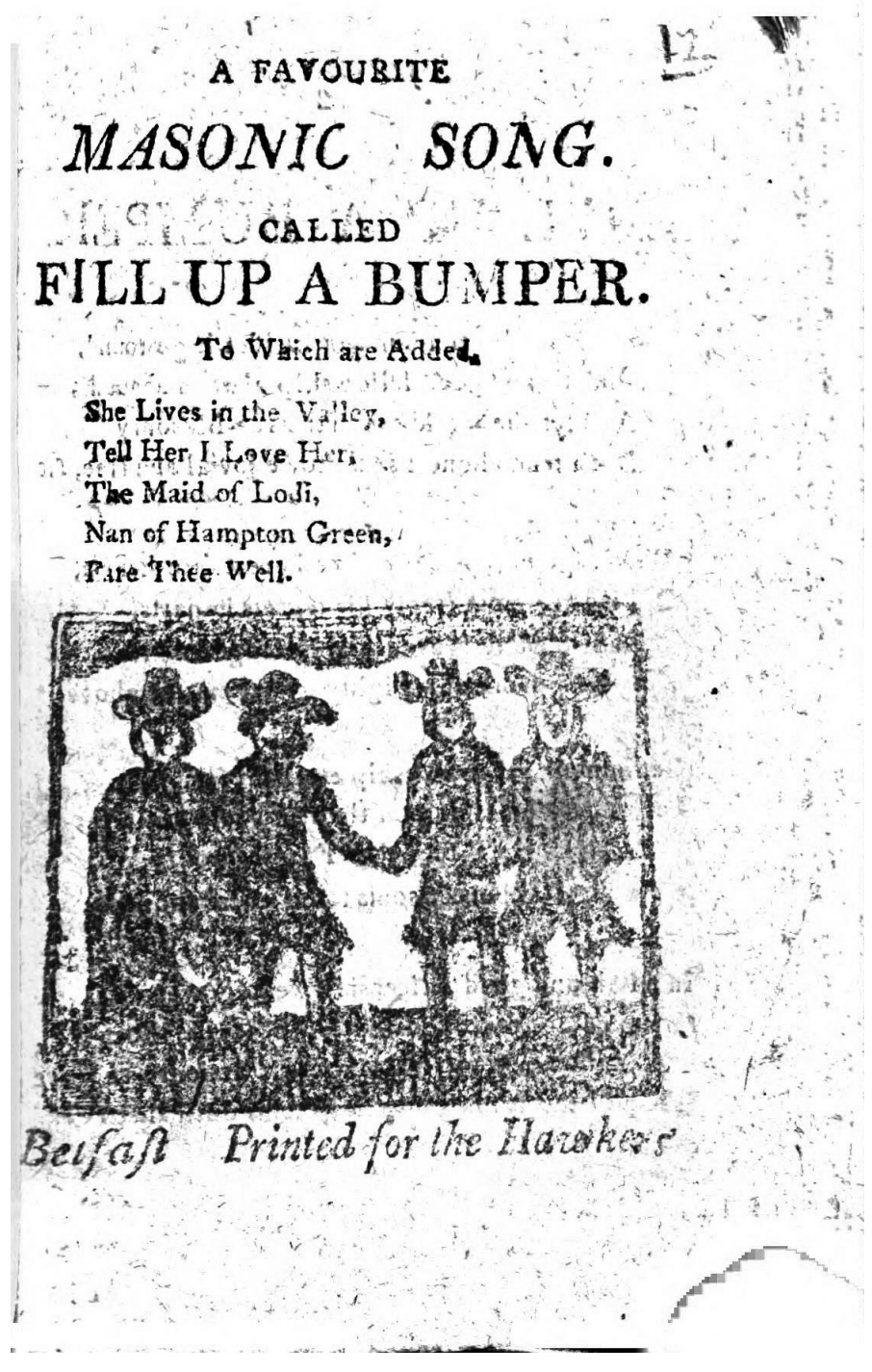




\section{Abstract \\ LIDIA IGNACZAK University of Łódź \\ ORCID: 0000-0001-9936-926X}

\section{SO-CALLED "VENETIAN SONG" HYPOTHESES ON ATTRIBUTION AND CULTURAL CIRCULATION OF AN ITALIAN SONG POPULAR IN THE AGE OF ENLIGHTENMENT}

The article discusses the circumstances accompanying the dissemination of one of the most popular European $18^{\text {th }}$ c. theatre melodies that, as so-called "Venetian song," was known to Warsaw audience from the year 1790 when, as Dominic's song was heard in Taczka occiarza (The Vinegar Maker's Wheelbarrow), a play translated and adapted to the Polish audience by Wojciech Bogusławski.

The paper also reveals the mechanisms that impede recognition of the melody's Italian original, namely the aria La mia crudel tiranna (The Maid of Lodi), from the year 1749 inserted into many European comic operas, and at the turn of the $18^{\text {th }}$ and $19^{\text {th }} \mathrm{c}$. was popular in salon music performances of various nature (from occasional, satirical songs of political character to freemasonic ballads).

The evidence of the strong presence of the "Venetian song" in the $18^{\text {th }}$ and $19^{\text {th }} \mathrm{c}$. music culture is found in many documents of the epoch, both in musical prints and in French, English, Irish, and American songbooks. The sources acknowledge the many variation transformations of the melody and its contrafact usage. 